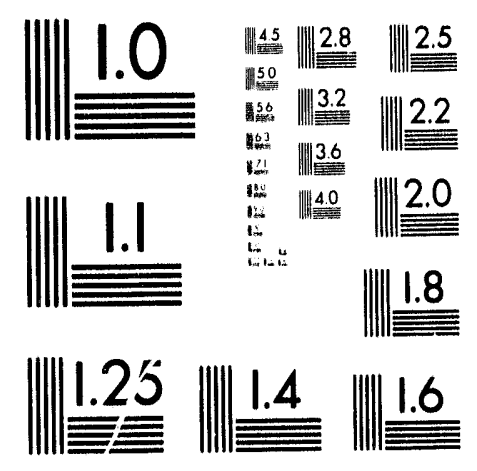



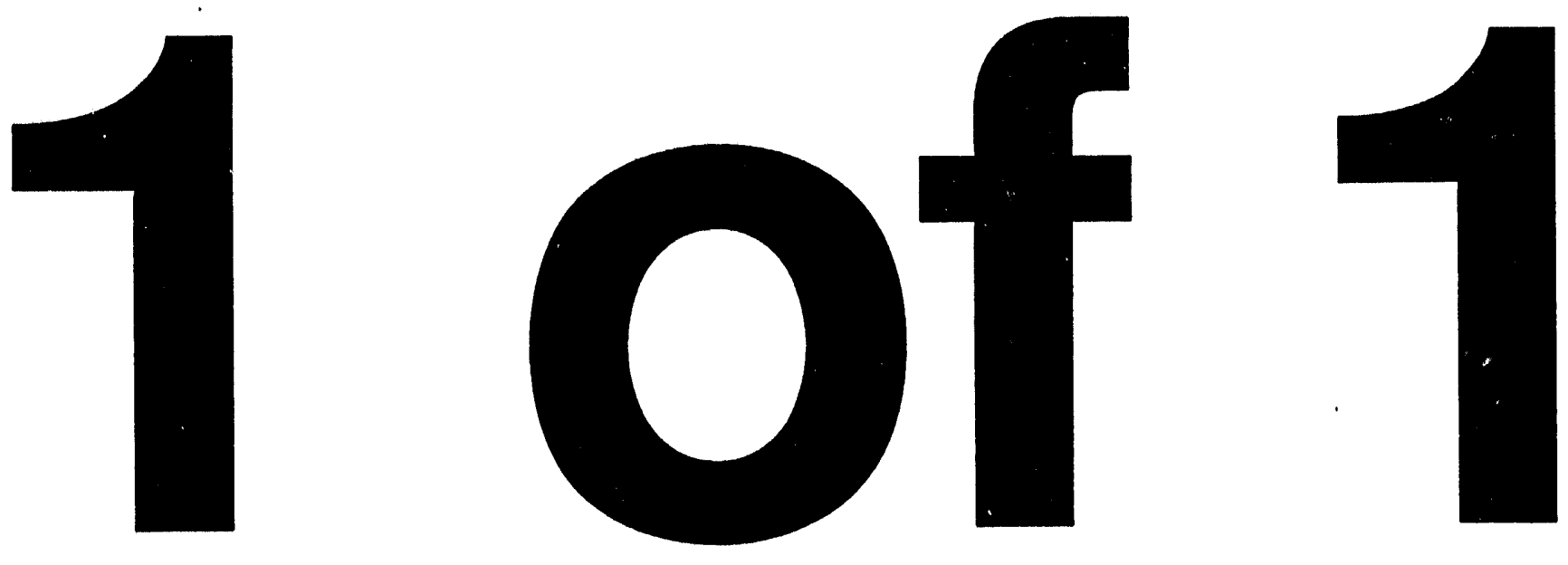
ARGONNE NATIONAL LABORATORY

9700 South Cass Avenue, Argonne, Illinois 60439

\title{
Preliminary Assessment Report for \\ Camp Swift Military Reservation, Installation 48070, \\ Bastrop County, Texas
}

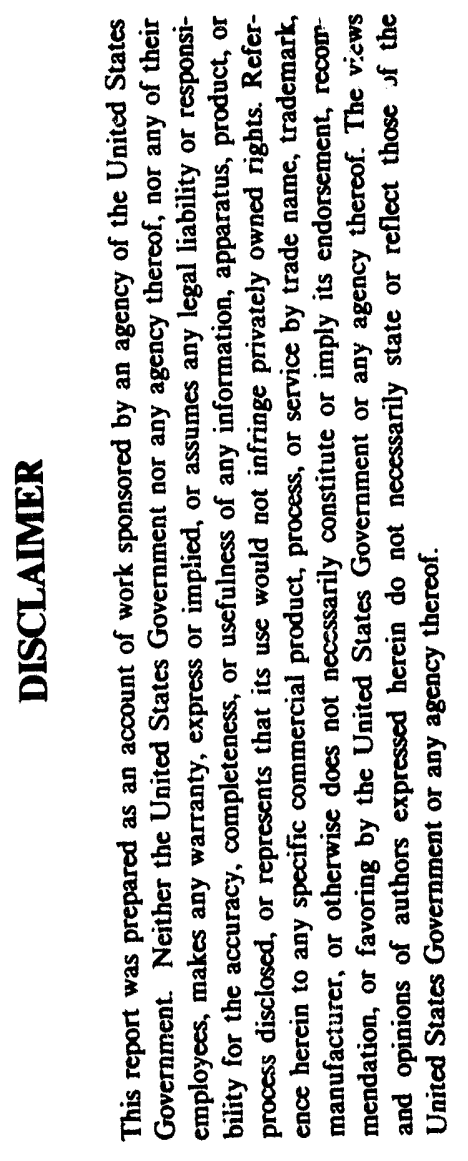

\author{
Prepared for \\ National Guard Bureau, Army Directorate \\ Aberdeen, Maryland
}

August 1993

Prepared by

Applied Geosciences and Environmental Management Section

Environmental Research Division

Argonne National Laboratory 


\section{\begin{tabular}{|l|l}
\hline REPORT DOCUMENTATION PAGE & FORM APPROVED
\end{tabular} \\ OMB No. 0704-0188}

Public reporting burden for this collection of information is estimated to average 1 hour per response, including the time for reviewing instructions, searching existing data sources, gathering and maintaining the data needed, and completing and reviewing the collection of information. Send comments regarding this burden estimate or any other aspect of this collection of information, including suggestions for reducing this burden to Washington Headquarters Services, Directorate for Information Operations and Reports, 1215 Jefferson Davis Highway, Suite 1204, Arlington, VA 22202-4302 and to the Office of Management and Budget, Paperwork Reduction Project (0704-01880), Washington, DC 20503.

\begin{tabular}{||c|c|c|}
\hline $\begin{array}{l}\text { 1. AGENCY USE ONLY } \\
\text { (Leave Blank) }\end{array}$ & $\begin{array}{c}\text { 2. REPORT DATE } \\
\text { August } 1993\end{array}$ & $\begin{array}{c}\text { 3. REPORT TYPE AND DATES COVERED } \\
\text { Preliminary site visit to complete assessment. }\end{array}$ \\
\hline
\end{tabular}

4. TITLE AND SUBTITLE
Preliminary Assessment Report for Camp Swift Military Reservation,
Installation 48070, Bastrop County, Texas

6. $\operatorname{AUTHOR}(S)$

5. FUNDING NUMBERS

Clyde B. Dennis

7. PERFORMING ORGANIZATION NAME(S) AND ADDRESS(ES)

Candace M. Rose

Argonne National Laboratory

9700 South Cass Avenue

Argonne. IL 60439

9. SPONSORING/MONITORING AGENCY NAME(S) AND ADDRESS(ES)

National Guard Bureau

Army Directorate

Aberdeen, MD 21010-5420

MIPR-3788

MIPR-4188

11. SUPPLEMENTARY NOTES

None.

12a. DISTRIBUTION/AVAILABILITY

Distribution is to goveknment agencies only.

Outside roquest must be made to the National Guard Bureau.

8. PERFORMING

ORGANIZATION

REPORT NUMBER

None

10. SPONSORING/

MONITORING AGENCY

REPORT NUMBER

IR-CR-93080

3. ABSTRACT (MAXIMUM 200 WORDS)

This report addresses the information necessary to complete the PA.

14. SUBJECT TERMS

17. SECURITY

REPORT

CLASSIFICATION OF

18. SECURITY CLASSIFICATION OF THIS REPORT

Unclassified

Unclassified
15. NUMBER OF PAGES

PA-70

16. PRICE CODE
19. SECURITY

CLASSIFICATION OF ABSTRACT

Unclassified 12b. DISTRIBUTION

CODE
20. LIMITATION OF

ABSTRACT

Unlimited 


\section{Contents}

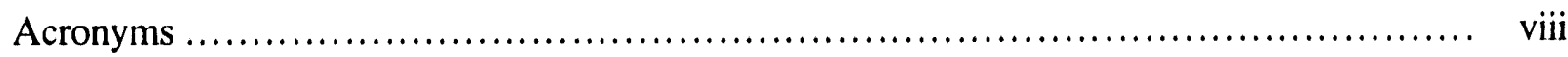

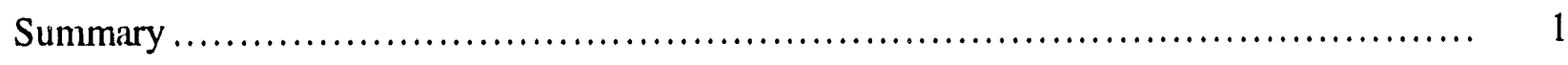

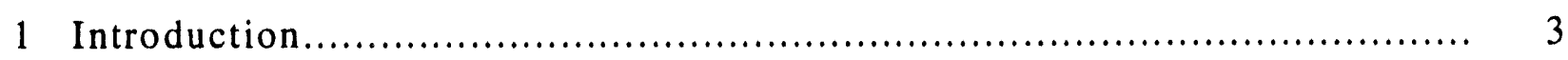

1.1 Authority for the Preliminary Assessment ............................... 3

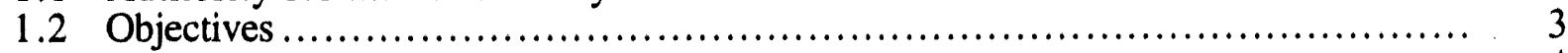

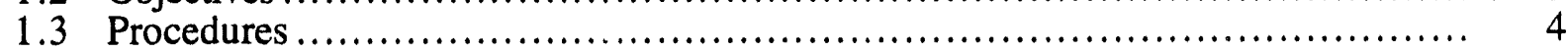

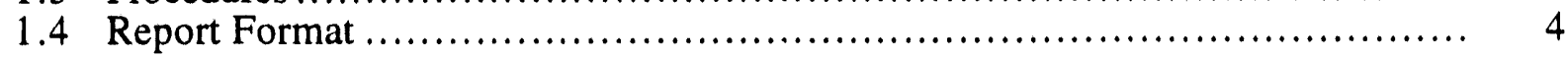

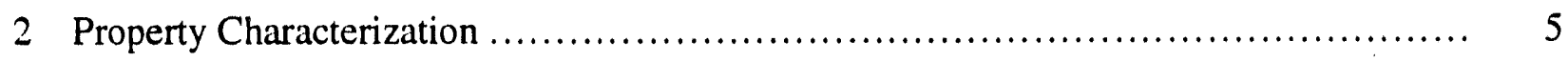

2.1 General Property Information ............................................ 5

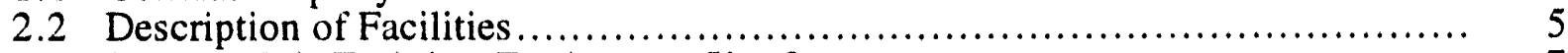

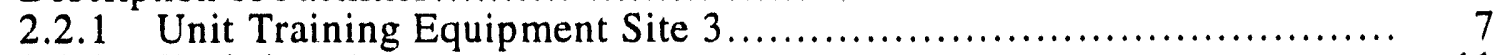

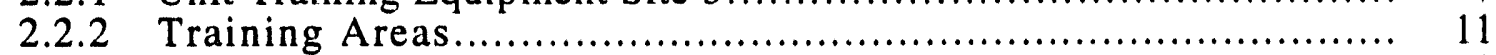

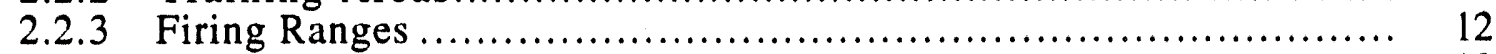

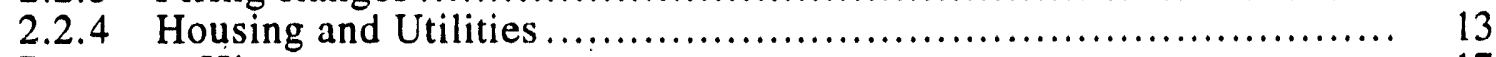

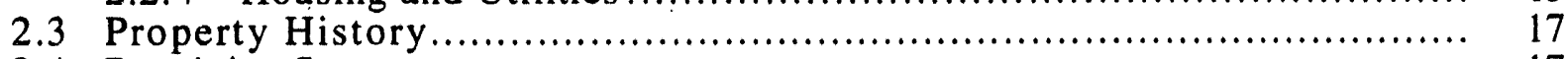

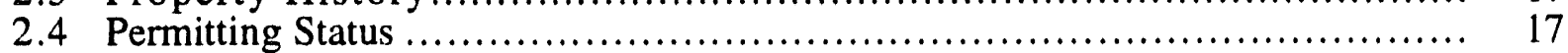

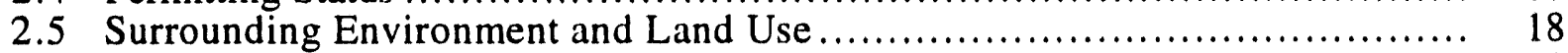

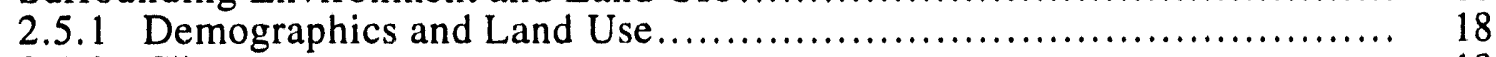

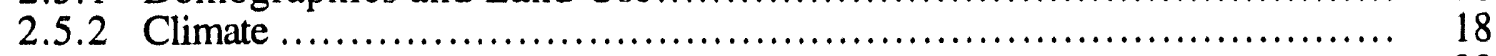

2.5.3 Surface Water and Physiography ....................................... 20

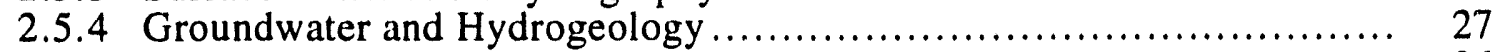

2.5.5 Sensitive Environments............................................... 36

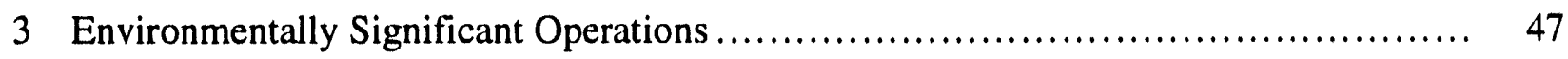

3.1 Storage of Hazardous Materials and Hazardous Waste ........................ 47

3.2 Underground Storage of Fuel and Waste Oil...................................... 47

3.3 Runoff of Potentially Contaminated Waste Water............................... 48

3.4 Detonation of Explosives ................................................. 48

4 Known and Suspected Releases .......................................... 49

4.1 Releases to Groundwater ................................................ 49

4.2 Releases to Surface Water ............................................... 49

4.3 Releases to Soil ......................................................... 49

4.4 Releases to Air ............................................................. 50

4.5 Other Releases ......................................................... 50

5 Human and Environmental Receptors....................................... 52

5.1 Groundwater........................................................ 52

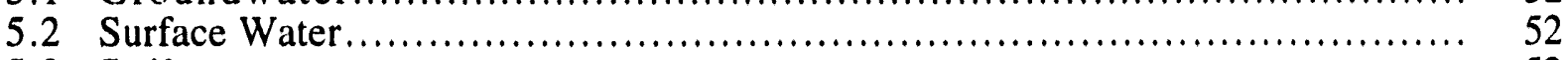

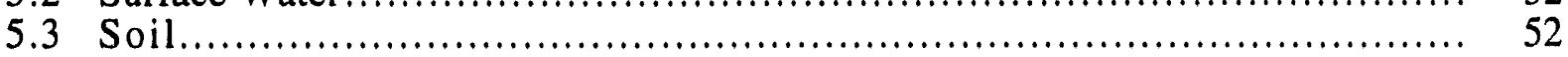

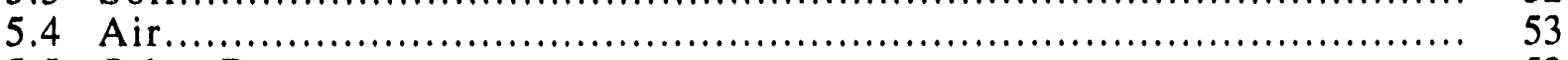

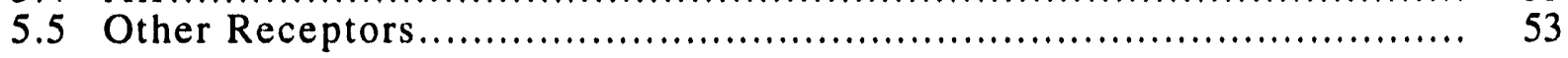




\section{Contents (Cont.)}

6 Preliminary Assessment Findings and Conclusions ........................... 54

6.1 Summary of Preliminary Assessment Findings ............................ 54

6.2 Recommendations for Further Action ...................................... 54

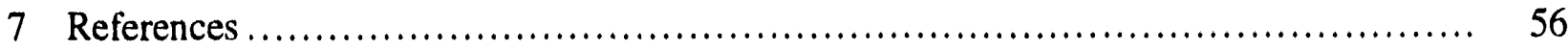

Appendix: Interview Information............................................... 59

\section{Figures}

1 General Location of Camp Swift Military Reservation .......................... 6

2 Locations of Camp Swift Training Areas and Activities ........................ 8

3 Camp Swift Unit Training Equipment Site 3................................... 9

4 Troop Billets in Training Area I .......................................... 15

5 Troop Billets in Training Area II ........................................ 16

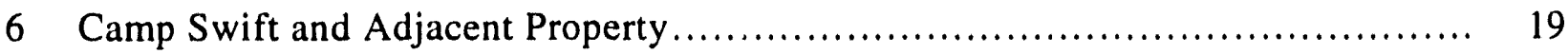

7 Major Physiographic Provinces of Texas................................... 21

8 Major Soil Associations Present at Camp Swift Military Reservation............... 23

9 Location of Regional Surface Waters...................................... 25

10 Flood Hazard Areas (100 year) within Camp Swift............................. 26

11 Geologic Map of Bastrop County, Texas ..................................... 28

12 Generalized Cross Section of Geology in the Vicinity of Camp Swift.............. 30

13 Locations of Aquifer Outcrops in the Vicinity of Camp Swift................... 34

14 Sources, Recharge, and Movement of Groundwater near Camp Swift............. 35

15 Well Locations of Major Water Users in the Vicinity of Camp Swift ............. 37

16 Number of Registered Wells Located in the T'exas Water Commission's Well-Numbering Grids near Camp Swift. 


\section{Tables}

1 Identifying Information for Camp Swift Military Reservation..................... 7

2 Petroleum, Oils, and Lubricants and Hazardous Materials Stored at Camp Swift Unit Training Equipment Site 3 ....................................... 10

3 Driller's Log of Well YD-58-54-507, near the Camp Swift Property .............. 32

4 Water Wells in the Vicinity of the Camp Swift Military Reservation.................. 39

5 Samples of Building Construction Materials Containing Asbestos ................ 51 


\section{Acronyms}

ACM asbestos-containing material

CERCLA Comprehensive Environmental Response, Compensation, and Liability Act

DOD Department of Defense

DOI Department of the Interior

DRMO Defense Reutilization and Marketing Organization

EPA U.S. Environmental Protection Agency

ESO environmentally significant operation

FISP Facility Inventory and Stationing Plan

IRP Installation Restoration Program

LAW light antitank weapon

NGB National Guard Bureau

NPDES National Pollutant Discharge Elimination System

PA preliminary assessment

POL petroleum, oils, and lubricants

TDWR Texas Department of Water Resources

TWC Texas Water Commission

TXARNG Texas Army National Guard

USACE U.S. Army Corps of Engineers

USGS U.S. Geological Survey

UST underground storage tank

UTES Unit Training Equipment Site 


\title{
Preliminary Assessment Report for \\ Camp Swift Milltary Reservation, Installation 48070, Bastrop County, Texas
}

\begin{abstract}
Summary
This report presents the results of the preliminary assessment (PA) conducted by Argonne National Laboratory at the Texas Army National Guard property in Bastrop County, Texas. Preliminary assessments of federal facilities are being conducted to compile the information necessary for completing preremedial activities and to provide a basis for establishing corrective actions in response to releases of hazardous substances. The principal objective of the PA is to characterize the site accurately and determine the need for further action by examining site activities, quantities of hazardous substances present, and potential pathways by which contamination could affect public health and the environment. This PA satisfies, for the Camp Swift property, the requirement of the Department of Defense Installation Restoration Program (IRP).
\end{abstract}

Camp Swift Military Reservation is located in the south-central portion of Texas, in Bastrop County. Camp Swift is approximately $30 \mathrm{mi}$ east of the city of Austin, the state capital. The property comprises 11,740 acres and is located in the Colorado River basin. The camp is federally owned and licensed to the Texas Army National Guard for military training. Camp Swift is a major training facility for Army National Guard units in central Texas. It is used for training in basic infantry skills, maneuver exercises, engineering skills, maintenance, helicopter operations, demolition, and pistol and rifle range firing. Organizational maintenance support is available through the Unit Training Equipment Site 3. Facilities are available to house 400 personnel.

The review of both historical and current practices at the property indicated that the activities at Camp Swift include no operations considered to have an adverse impact to the environment. The recommendation, therefore, is that no further IRP action is necessary at this property. 


\section{Introduction}

This document is a report of the preliminary assessment (PA) conducted by Argonne National Laboratory at the Texas Army National Guard (TXARNG) property known as Camp Swift Military Reservation, located in Bastrop County, Texas.

\subsection{Authority for the Preliminary Assessment}

$\mathrm{Ti}$ ث National Guard Bureau, Army Directorate, has engaged Argonne to perform PAs of selected National Guard properties. These assessments are being done in a manner consistent with both the Department of Defense (DOD) Installation Restoration Program (IRP) and the U.S. Environmental Protection Agency's (EPA's) Potential Hazardous Waste Site Preliminary Assessment Guidance. Preliminary assessments of National Guard properties are conducted under the authority and direction of the IRP; the Comprehensive Environmental Response, Compensation, and Liability Act (CERCLA or, more commonly, Superfund); and the Superfund Amendments and Reauthorization Act of 1986 (Public Law 99-499).

\subsection{Objectives}

This PA report is based on existing information from the National Guard records that were made available to Argonne investigators and from other sources. Although this PA effort did not extend to the generation of new data, it nonetheless identifies areas where existing data are incomplete, unreliable, or ambiguous and recommends ways to address such shortcomings.

The objectives of the PA are to satisfy the requirements of the IRP and to

- Identify and characterize the environmentally significant operations (ESOs),

- Identify property areas or ESOs that may require a site investigation,

- Identify ESOs or areas of environmental contamination that may require immediate removal,

- Identify properties for which no further action is needed, and 
- Provide information sufficient to prescore the site with the EPA's PA Scoresheets (September 1991).

\subsection{Procedures}

The PA began with a review of National Guard files located at the Texas Division of Military Affairs Headquarters at Camp Mabry in Austin, Texas, on May 24, 1993. Other relevant information was obtained from publications by the U.S. Geological Survey; the Department of the Interior's Office of Surface Mining, Reclamation, and Enforcement and Bureau of Land Management; the U.S. Army Corps of Engineers; the Department of Agriculture Soil Conservation Service; and the Texas Water Development Board. A site visit was conducted on May 26 to obtain additional information through direct observation and interviews with personnel familiar with the property and its operations.

\subsection{Report Format}

This PA report presents a summary and evaluation of the data relevant to the PA for this property. Section 2 describes the property and its surrounding environment and land uses. Section 3 identifies and characterizes the ESOs at the site. Section 4 discusses known and suspected releases to the environment, and Section 5 discusses potential human and environmental receptors for such releases. Section 6 summarizes the findings and conclusions, discusses the quality and reliability of the supporting information, identifies areas requiring further action, and (as appropriate) suggests how such actions can be accomplished. Section 7 lists pertinent materials reviewed. The Appendix gives interview information. 


\section{Property Characterization}

\subsection{General Property Information}

Camp Swift Military Reservation is located in the south-central portion of Texas, in Bastrop County. The property is located approximately $8 \mathrm{mi}$ north of the city of Bastrop, the county seat. Approximately $30 \mathrm{mi}$ west of the reservation, in Travis County, is the city of Austin, the state capital. The federally owned property, licensed to the TXARNG for military training, comprises 11,740 acres (TXARNG 1988a). This represents approximately $2 \%$ of the acreage in Bastrop County (Baker 1979). The vicinity of Camp Swift is primarily agricultural, with scattered low-density suburban residential areas. The $18-\mathrm{mi}^{2}$ reservation is one of the few tracts of federal land in Texas underlain by commercially strippable lignite (Gaylord et al. 1985). The Camp Swift lignite reserve, recoverable by surface mining methods, is estimated to be approximately $25 \%$ of the recoverable lignite resource in Bastrop County. Figure 1 shows the general location of the property, and Table 1 lists pertinent information about it.

\subsection{Description of Facilities}

Camp Swift is a major training facility for TXARNG units (TXARNG 1988a). In the 11,706 acres available for field training, individual and crew-served weapon ranges and training areas are provided to support annual training and inactive duty training for aviation, airborne, engineer, armor, artillery, and mechanized infantry units. Organizational maintenance support is provided through the Unit Training Equipment Site 3 and its supporting facilities, which occupy the remaining 34 acres. Housing is available in the training areas for the Texas National Guard Academy to conduct weekend and annual training for Officer Candidate School, NonCommissioned Officer Schools, the Basic Medical Specialist Course, and other schools requiring field training. Camp Swift is also used by the Reserve Officer Training Corps, the U.S. Army Reserves, police, civil defense, and public educational institutions when these activities do not interfere with military training. Figure 2 identifies the general locations of training areas and activities. 

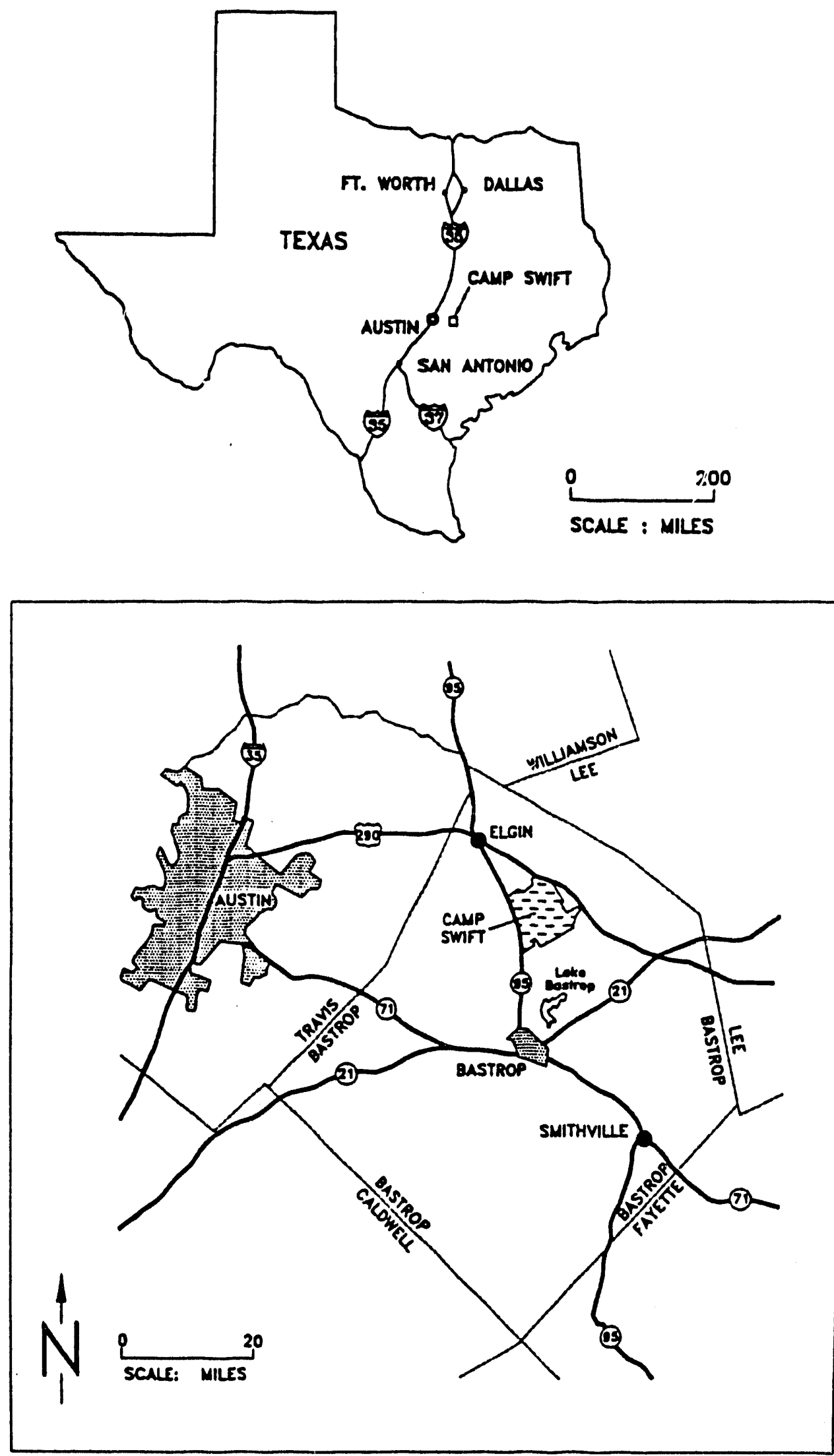

FIGURE 1 General Location of Camp Swift Military Reservation (Source: DOI 1980) 
TABLE 1 Identifying Information for Camp Swift Military Reservation

\begin{tabular}{ll}
\hline Property address & $\begin{array}{l}\text { Camp Swift Military Reservation } \\
\text { Texas Army National Guard } \\
\text { Route 2, Box 151-X } \\
\text { Bastrop, Texas 78602 }\end{array}$ \\
$\begin{array}{l}\text { Property location } \\
\text { Latitude } \\
\text { Longitude }\end{array}$ & $\begin{array}{l}30^{\circ} 17^{\prime} \mathrm{N} \\
97^{\circ} 17^{\prime} \mathrm{W}\end{array}$ \\
Installation no., FiSpa & 48070 \\
Installation commander & Lt. Junot \\
Facility types & $\begin{array}{l}\text { Training site } \\
\text { Unit Training Equipment Site } \\
\text { Armory }\end{array}$ \\
Range
\end{tabular}

a Facility Inventory and Stationing Plan.

\subsubsection{Unit Training Equipment Site 3}

The Unit Training Equipment Site 3 (UTES 3) is in the southwestern portion of the TXARNG property. UTES 3 provides facilities for maintenance of the approximately 60 wheeled and tracked vehicles assigned to the unit. Operations performed include general vehicle maintenance, vehicle fueling, and vehicle and equipment washing. Vehicle maintenance activities include fluid changes (i.e., oil, transmission fluid, and antifreeze/coolant), filter changes (gas, oil, air, and transmission filters), brake repair, lubrication of axles and drive trains, battery changes, tire repair and replacement, engine repair, transmission repair, electronic repair, minor welding and bc ty repair, and minor spot painting. A diagram of UTES 3 and its supporting facilities is provided as Figure 3. This is the only location at Camp Swift where hazardous materials and hazardous wastes are stored (TXARNG 1988b). A summary of petroleum, oils, and lubricants (POL) and hazardous materials stored is provided in Table 2. 


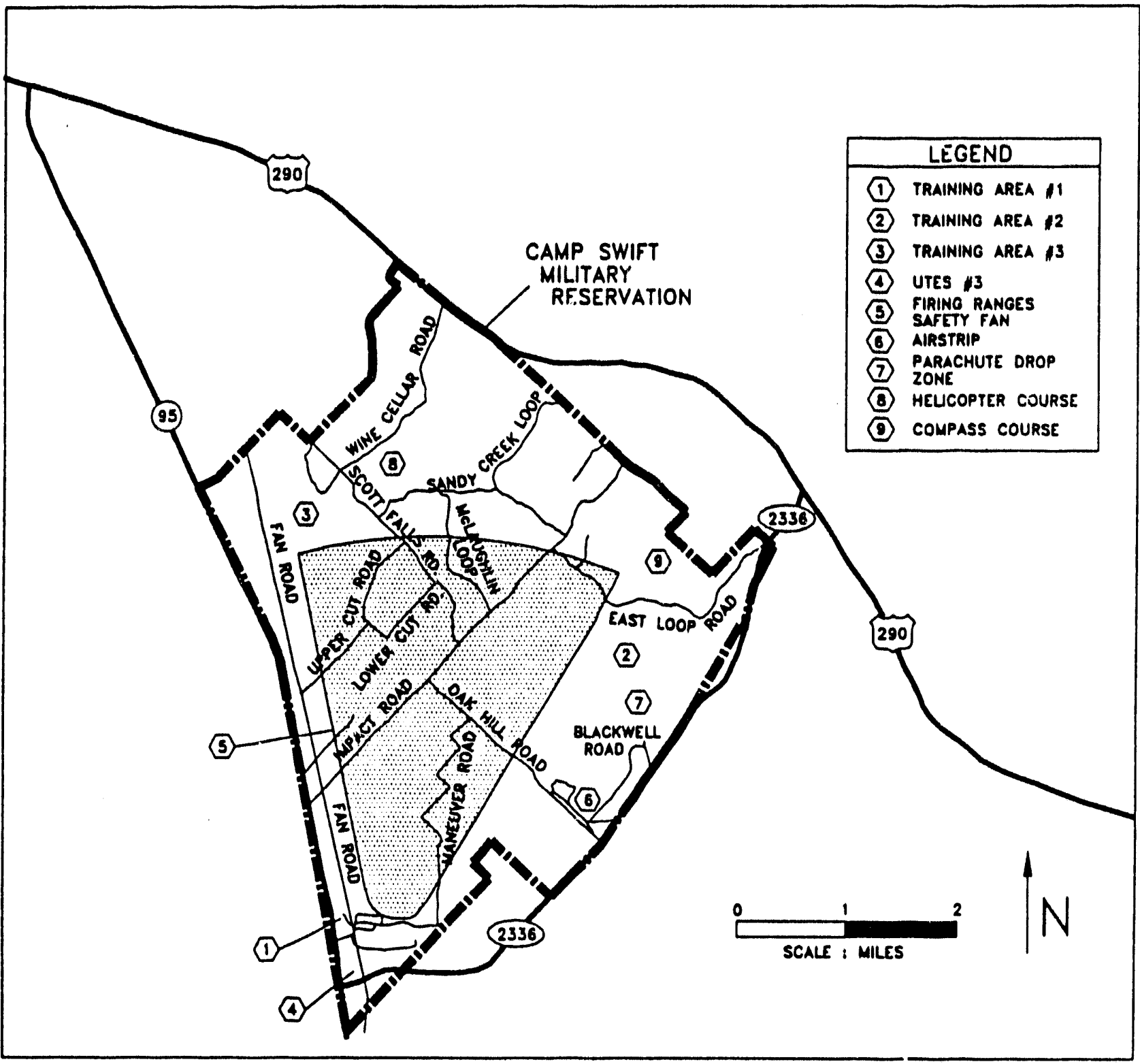

FIGURE 2 Locations of Camp Swift Training Areas and Activities (Source: TXARNG 1988a) 


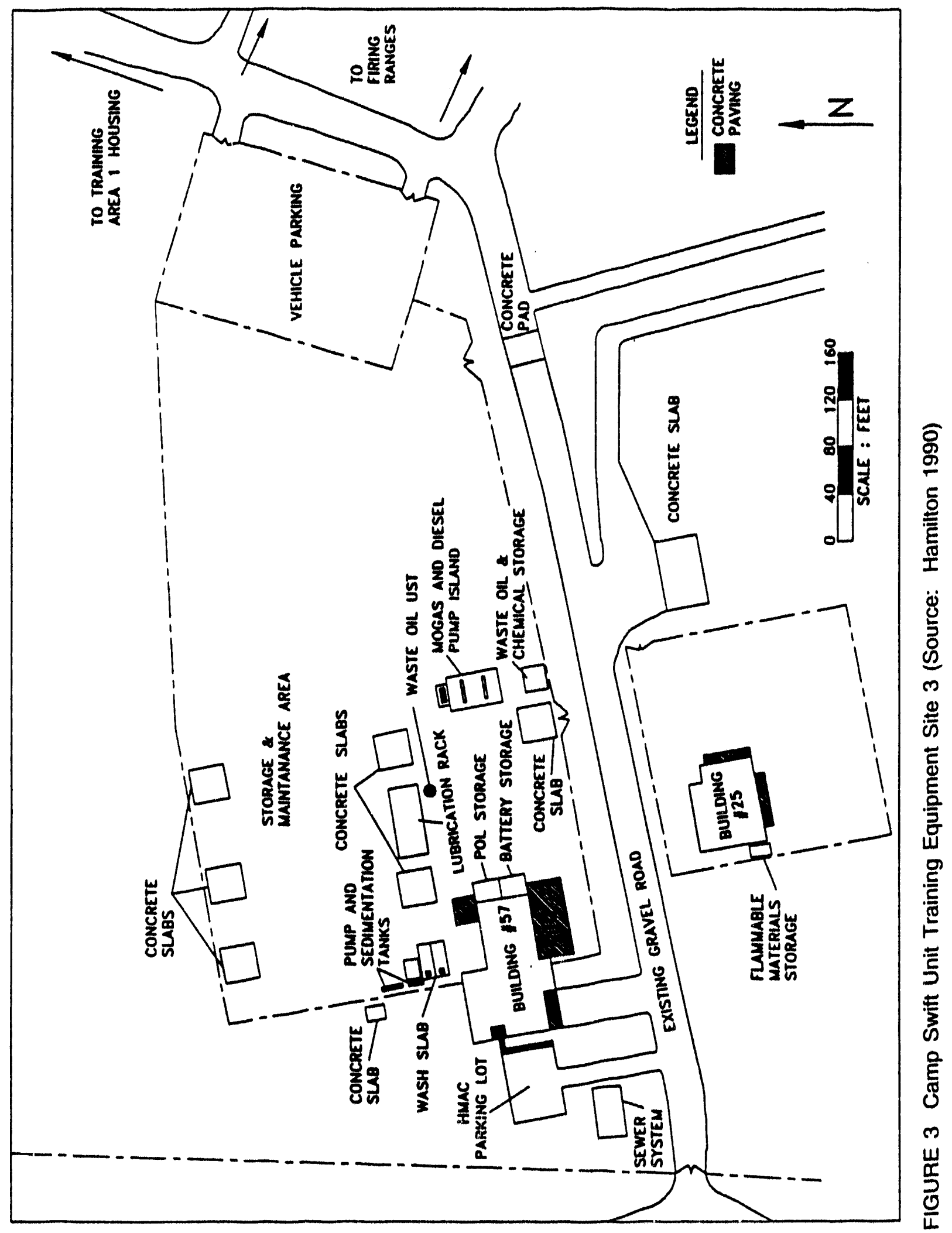


TABLE 2 Petroleum, Olls, and Lubricants and Hazardous Materials Stored at Camp Swift Unit Training Equipment Site 3

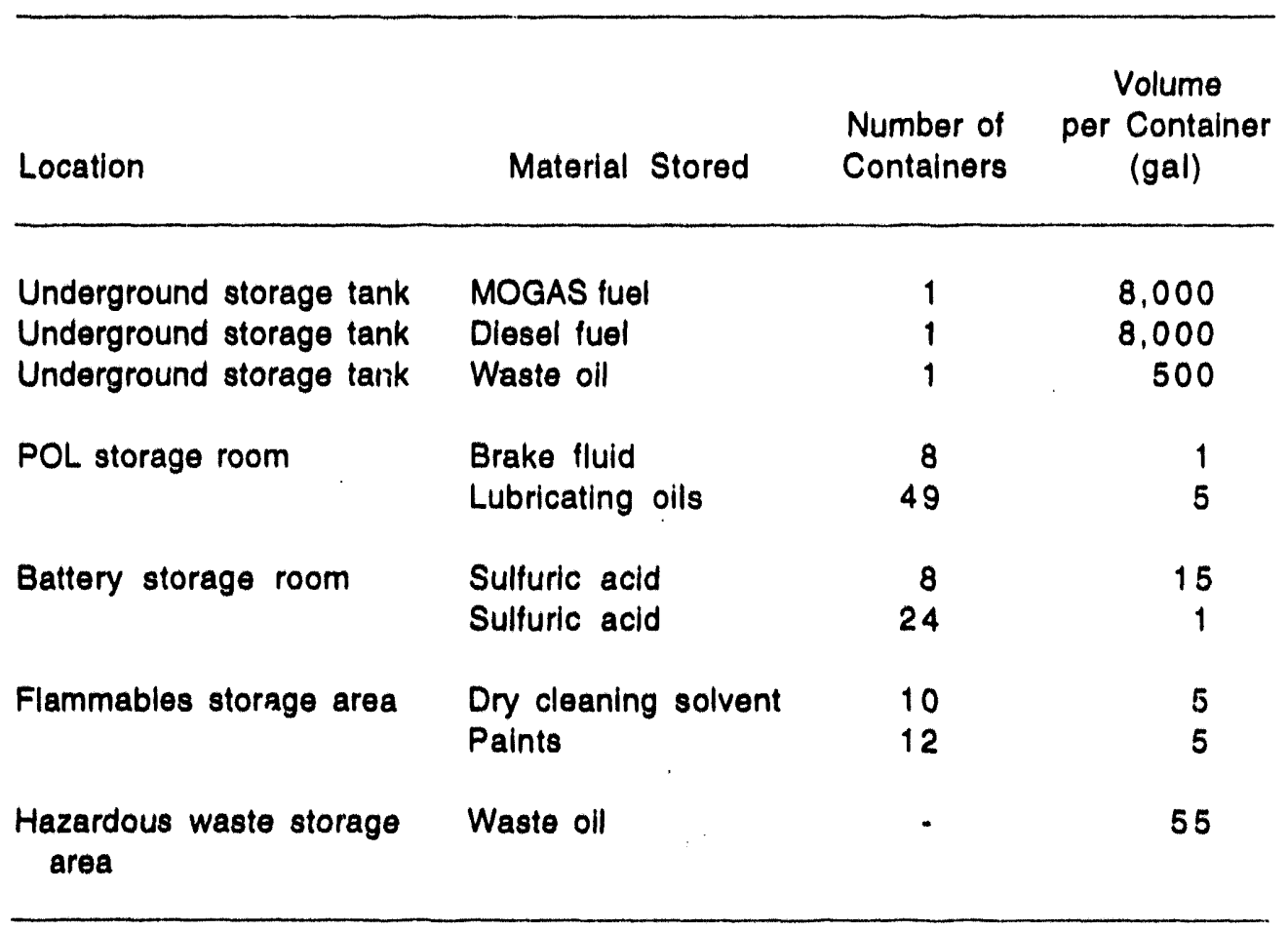

Source: TXARNG (1988b).

Building 57 (the main shop) is a single-story structure, $7,163 \mathrm{ft}^{2}$ in area, set on a concrete slab foundation with concrete walls and an asphalt roof (USACE 1993). It was constructed in 1987. The western portion of Building 57 consists of offices, supply and storage rooms, latrines, and a break room. The inner walls are primarily wallboard. Most floors and ceilings are tile covered. The eastern portion of the building consists of a large open bay with four maintenance work areas. The walls are metal with block wall insulation, and the ceiling is metal. The floor is exposed concrete. Drains within the shop area lead to an oil-water separator. A steel 500-gal underground storage tank (UST), installed in 1987 with cathodic protection, receives waste oil removed from vehicles during maintenance activities and from the oil-water separator. The UST is on the northeast side of Building 57, near the tank lubrication rack. The oil-water separator is located south of $\Sigma$ tilding 57 (TXARNG 1988b).

A vehicle/equipment wash area within the Building 57 work area also drains to the oilwater separator. As designed, filtered waste water was directed to a ditch south of the UTES facility, while the separated waste fluids were directed into the 500-gal waste oil UST. Use of the wash area is currently on hold pending interconnection with the regional waste water treatment 
system. Use of the outdoor vehicle wash area located north of Building 57 with drainage though sediment-holding tanks is also on hold pending connection to the waste water treatment system.

The POL storage area and the battery storage area are slab rooms attached to the eastern wall of the Building 57 work bay. Access to the storage areas is from outside Building 57 and is restricted by key. Both storage rooms have concrete floors with no floor drains. The total area of the attached storage rooms is $440 \mathrm{ft}^{2}$. New or unused petroleum products are stored in the POL storage area.

The hazardous waste storage area is southeast of Building 57. The bermed, metal-roofcovered, fenced shed typically contains several 55-gal drums of waste fluids awaiting shipment to the Defense Reutilization and Marketing Organization (DRMO) for disposal.

Fuel is stored at this facility in two 8,000-gal USTs installed in 1987 (TXARNG 1988b). The double-walled fiberglass tanks and associated fuel-dispensing island are east of the UTES 3 facility (Figure 3). In addition, fuel is stored in each vehicle's fuel tank. Normal throughput of fuel at this facility is approximately $1,250 \mathrm{gal}$ of diesel fuel and $500 \mathrm{gal}$ of MOGAS per month (Dennis 1993).

The Building 25 armory is a single-story structure, $2,637 \mathrm{ft}^{2}$ in area, set on a concrete slab foundation with steel walls and a steel roof (USACE 1993). The building consists of a large open warehouse, a front office, a supply room, latrines, and a vault. The armory has an attached trailer that provides space for three offices. A flammable materials storage shed adjacent to Building 25 is on a cement slab with concrete block walls and concrete roof construction (USACE 1993). The area of the detached storage shed in $144 \mathrm{ft}^{2}$. Before the Building 57 UTES facility was constructed, organizational maintenance support services were provided at Building 25 . Use of a concrete pad east of Building 25 as a wash area was terminated when the Building 57 facility was constructed.

\subsubsection{Training Areas}

Camp Swift is used for training in basic infantry skills, tank and troop maneuver, engineer skills, maintenance, helicopter operations, use of firearms, and demolition (TXARNG 1988a). The property is roughly divided into three training areas. Training Area I, north of the cantonment area, includes the firing ranges and a squad-sized chemical confidence chamber. Housing facilities 
are to the west of the firing ranges. Training Area II, in the eastern portion of the property, includes the 2,000-ft grass-surfaced airstrip and parachute drop zone. Three compass courses are located within an area of 80 acres northeast of the drop zone. Housing in the training area includes a parachute shakeout facility. The airfield is used for tactical helicopter landings. No traffic patterns or takeoff and approach paths are specified for the property or surrounding areas. Training Area III, in the northern portion of the property, is used for tank and troop maneuver operations and also contains a slalom course for helicopter flight training.

\subsubsection{Firing Ranges}

Eight ranges at Camp Swift provide for both individual and crew weapons training (TXARNG 1989). The types of firing ranges include the following:

- The pistol (turning target) range, with 10 firing positions, used for familiarization and qualification firing of 0.45 caliber pistols (or smaller) and the M3 submachine gun. The turning target mechanisms are operated manually. Range facilities include a target storage shed.

- The combat pistol qualification range, with 15 firing positions, designed to provide combat qualification for the M1911 and M9 semiautomatic pistols. Each lane has seven automatic pop-up silhouette targets electrically controlled from the range tower. Range facilities include the control tower, an ammunition issue building, a target shed, and latrines.

- The 600-m known-distance range, with 37 firing positions, for familiarization and qualification firing of $\mathrm{M} 16 \mathrm{~A} 1 / \mathrm{A} 2$ rifles and $\mathrm{M} 14$ rifles and familiarization firing of the M60 machine gun. Firing lines are located at $100-\mathrm{m}$ intervals from 100 to $600 \mathrm{~m}$. The range also provides for qualification firing of the M16A1/A2 with the standard course qualification target. Range facilities include a target shed.

- The M16 automated record fire range, with 16 firing positions, designed for zero and qualification firing of the M16A1/42 rifle. Each lane is equipped with seven pop-up silhouette targets electrically controlled from the tower. Range 
facilities include a control tower, an ammunition issue building, a target shed, and latrines.

- The M2/M60 machine gun field fire transition range, with 8 permanently constructed firing positions, for familiarization and field firing qualification of the M2 and M60 machine guns. The full-scale range has 11 automatic pop-up silhouette targets electrically controlled from the tower. Range facilities include a control tower, an ammunition issue building, a target shed, and latrines.

- The M72/M203 range, with three firing positions, for familiarization firing of the M72 light antitank weapon (LAW) and the M203 grenade launcher. Each firing position has a zero panel, an open window/door target, a bunker target, a vehicle target, and a troop target.

- The demolition/land mine warfare range for familiarization with setting and detonation of a variety of explosive charges ( $40 \mathrm{lb}$ maximum).

- The hand grenade range, used for familiarization firing of the M61 and M67 fragmentation grenades. The full-scale range has four tiring bays and one observation bunker.

Total acreage set aside for firing range use is 2,065 acres, excluding the 348 -acre demolition or dud area. Of this, the buffer zones occupy 296 acres, and the safety zones occupy 1,769 acres (DOD 1982).

\subsubsection{Housing and Utilitios}

On the basis of troop usage data, the National Guard Bureau (NGB) determined that the size of Camp Swift for training purposes is 700 persons (i.e., one battalion size unit) (NGB 1986). Approximately 20 full-time employees are at Camp Swift, but sufficient hutments and trailers are located in Training Area I and Training Area II to house 400 personnel (TXARNG 1989). No medical facility is at the site. The boundary of Camp Swift is completely fenced with five strands of barbed wire strung on metal posts. 
The troop billets and administrative buildings in Training Area I are shown in Figure 4 (TXARNG 1989, NGB 1988). Building $1\left(1,800 \mathrm{ft}^{2}\right)$ is a dining facility capable of accommodating up to 150 personnel in a standup eating arrangement. Cooking and food storage appliances include three freezers, two refrigerators, two gas ranges, a steam serving table, and a food preparation table. Building $2\left(180 \mathrm{ft}^{2}\right)$ and Building $4\left(192 \mathrm{ft}^{2}\right)$ are permanent field latrines. Buildings 12-15 and 18-23 (520 $\mathrm{ft}^{2}$ each) are troop hutments capable of housing 18 personnel each. Building $16\left(520 \mathrm{ft}^{2}\right)$ is a unit administrative building. It also has sleeping accommodations for four personnel. Building $17\left(520 \mathrm{ft}^{2}\right)$ is a unit supply building. Building $26\left(720 \mathrm{ft}^{2}\right)$ is a trailer for female or staff personnel. It can house 13 persons and has a latrine and shower. Building $28\left(1,280 \mathrm{ft}^{2}\right)$ is a bathhouse with hot and cold running water.

The troop billets and administrative buildings in Training Area II are shown in Figure 5 (TXARNG 1989, NGB 1988). Building $11\left(180 \mathrm{ft}^{2}\right)$ is a permanent field latrine. Building 36 $\left(1,080 \mathrm{ft}^{2}\right)$ is a bathhouse and latrine facility with hot and cold running water, sinks, commodes, and urinals. Buildings 37.46 (average $552 \mathrm{ft}^{2}$ ) are troop trailers capable of housing 18 persons each. Buildings 5 and $7\left(1,800 \mathrm{ft}^{2}\right.$ each) are dining facilities capable of accommodating 200 personnel in a standup eating arrangement. Cooking and food storage appliances include a freezer, a refrigerator, and a gas range. Building $47\left(575 \mathrm{ft}^{2}\right)$ and Building $48\left(448 \mathrm{ft}^{2}\right)$, with latrine and shower facilities, are trailers for women and staff members, capable of housing 12 persons each.

The water for Camp Swift is supplied by Aqua Water Company in Bastrop (TXARNG 1988a). The site water system has a capacity of $144,000 \mathrm{gal}$ per day and can, without replenishment, support the approximately 20 full-time staff and about 450 additional personnel for a 3- to 4-day training period. An 1,800-gal pressurized water tank and pump have been installed in Training Area II to adequately support the bathhouse (Building 36 ) located there.

Site sewage facilities include five septic tanks (TXARNG 1988a). Four 750-gal tanks support (1) the UTES 3 facility, (2) Building 25, (3) the Building 1 field kitchen and the Building 26 housing unit in Training Area I, and (4) the Building 47 and 48 housing units in Training Area II. A 1,000-gal tank supports 120 people using the Building 36 bathhouse in Training Area II for a 3- to 4-day training period.

The property is supplied with propane and butane by E.O. Sharp Butane Gas Co. The site has three 1,000-gal propane tanks and one 250-gal butane tank. Electricity is supplied by Bluebonnet Electric Cooperative, Inc., via an overhead 7,200-V electrical distribution system. All lines are single phase (110 V), and four transformers are on the post (TXARNG 1988a). 


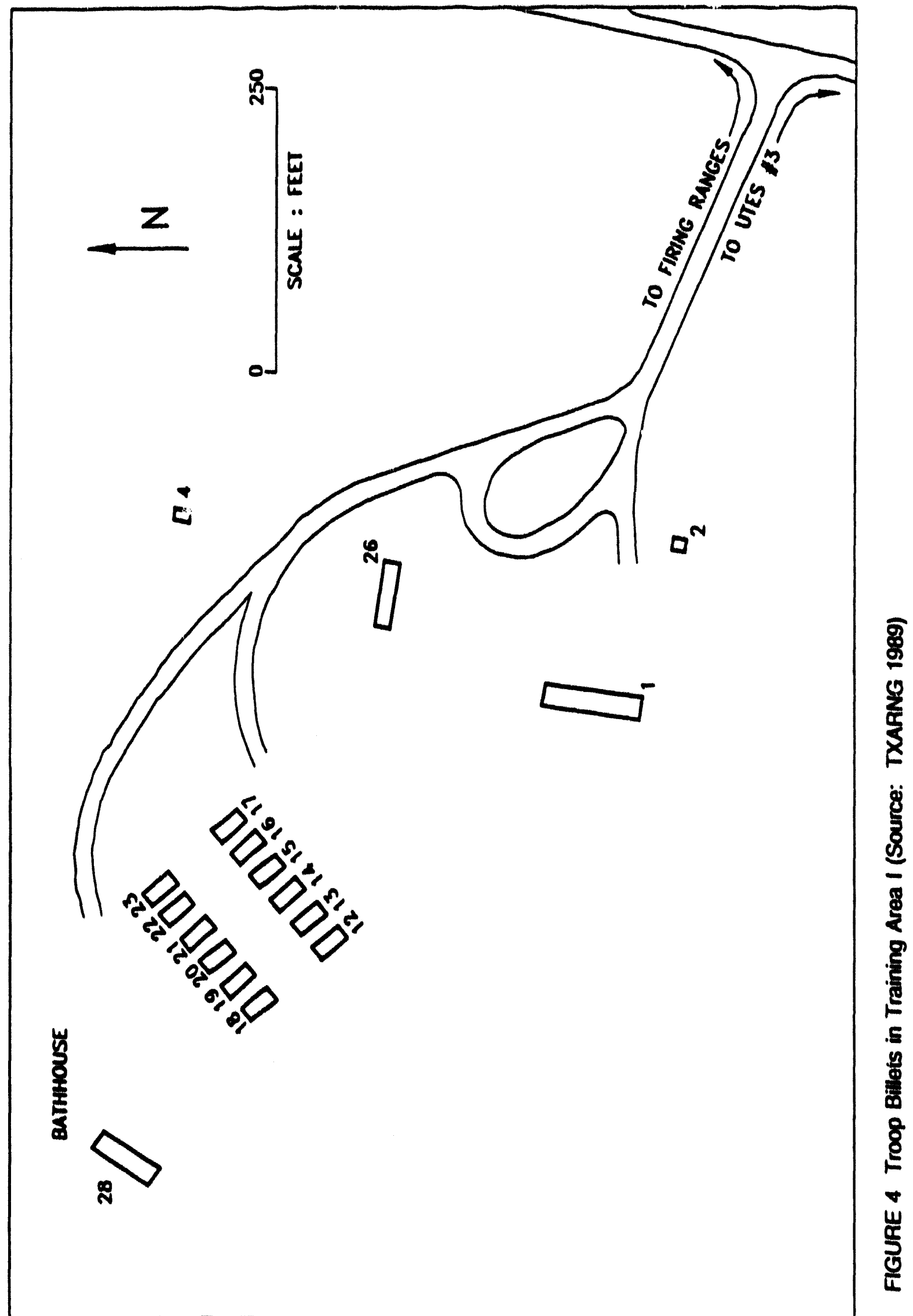




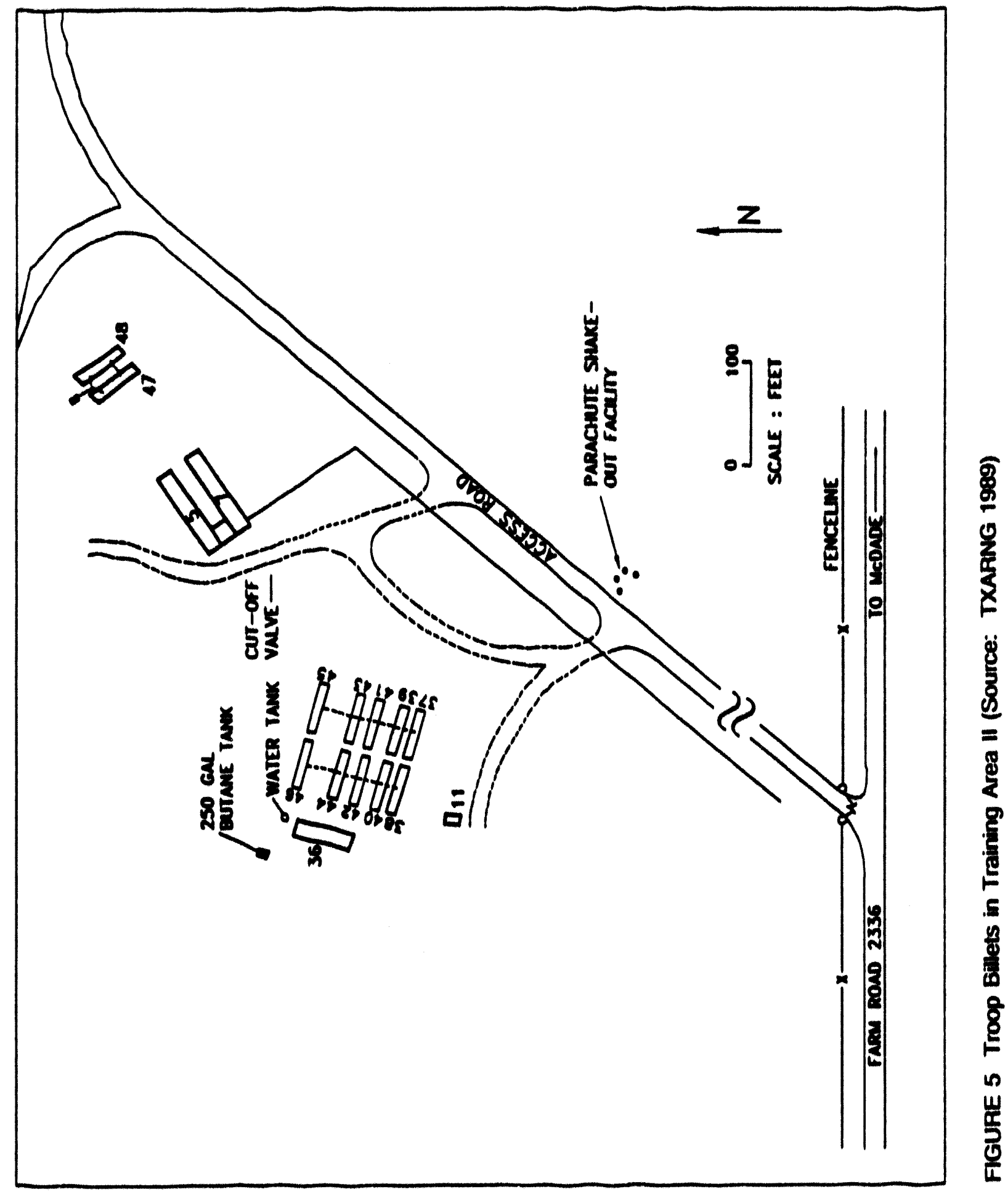




\subsection{Property History}

In 1941, to meet the military training requirements of World War II, Bustrop County was selected as the site of a U.S. Army camp. Approximately 2,500 acres of land were donated, and another 97.000 acres were leased. When war was declared, the War Department took possession of 52,000 acres of the available land, involving 355 separate tracts. The camp, named after Major General Eben Swift, was used throughout the war for the training of up to 30,000 men at one time. Camp Swift was closed in 1946 as an active military training site, and most of the land reverted to private ownership.

The remaining federally owned Camp Swift property, consisting of 11,740) acres, was licensed to the TXARNG for military training purposes, effective January 1, 1958, for a period of five years. Subsequent license agreements were issued for periods of one or five years. Effective March 24, 1977, a 64-acre tract of the Camp Swift property was set aside for lease to the city of Bastrop for use as a sanitary landfill for a period of 25 years. The TXARNG retained use of 11,676 acres, and effective January 1, 1978, the lease agreement was extended for a 25 -year period. Because of public opposition, the 64-acre tract was never activated by the city of Bustrop as a landfill, and the lease agreement between the DOD and the city of Bastrop was rescinded in 1980 (DOD 1982).

\subsection{Permitting Status}

This installation has no ESOs that require permits under the Resource Conservation and Recovery Act, and none are designated for CERCLA activities. Because of its solid waste management activities, UTES 3 is registered with the Texas Department of Health as a smallquantity waste generator, identification number 66296 (Bennett 1985). The USTs are registered with the Texas Water Commission, owner identification number 01721 (TWC 1990). On-site sewage treatment facilities are individual septic tank systems that meet Texas rules restricting each nonpermitted septic system to treatment of less than 5,000 gal per day (EPA 1989). A regional waste water treatment facility has been constructed approximatelv $3 \mathrm{mi}$ south of the Camp Swift property (HDR 1991). At the time of the site visit, interconnection with the treatment facility was planned. The oil-water separator discharge adjacent to the UTES is not currently included as a discharge source on the National Pollutant Discharge Elimination System (NPDES) list. 


\subsection{Surrounding Environment and Land Use}

\subsubsection{Demographics and Land Use}

Camp Swift is located in the predominantly suburban area of forest and agricultural lands covering most of Bastrop County. Farming of cotton, grain, and sorghum and raising of beef cattle are the major land uses. The area adjacent to Camp Swift is private property, most of which is used in agricultural operations. Figure 6 identifies the existing Camp Swift boundary and adjacent properties. State Highway 290 runs along the eastern border of Camp Swift, and State Highway 95 runs along the western border. Furm-to-Market Road 2336 runs along the southern border of the TXARNG property, connecting the two state roads. A small business (a cattle rendering plant) is located at the southwest comer of the post. The University of Texas Environmental Science Park, a cancer research center, is located near the southern boundary of the TXARNG facility. Part of that site is used for the grazing of test animals. A five-acre portion of the site (at the eastern corner) has been leased to the Bastrop County Volunteer Fire Department. An automobile wrecking yard is located at the northeastern boundary of the site. Farther north is the Elgin Brick Company.

Three small residential communities are located adjacent to Camp Swift. Sayersville, separated from the reservation by Highway 95, is near the northwest corner of UTES 3. McDade and Butler are enst of Camp Swift. Together, these three communities have an estimated population of 500 persons. The population closest to Camp Swift would be that residing in Sayersville, approximately 0.5-0.75 $\mathrm{mi}$ from the camp boundary. The nearest population centers are Bastrop (to the south) and Elgin (to the north). Camp Swift is located directly between the two towns, $8 \mathrm{mi}$ from each, on Highway 95. The population of Bastrop is 4,044, and the population of Elgin is 4,846. Austin, the state capital and the nearest large city, is 30 mi east of Camp Swift. Austin has a population of 465,622 (Rand McNally 1992).

\subsubsection{Climate}

The climate of the Camp Swift area is classified as subtropical (DOI 1982). Humid, tropical weather dominates during the summer, and continental weather patterns predominate during the remainder of the year. The mean annual temperature is about $68^{\circ} \mathrm{F}$. January is the coldest month, with an average low temperature of approximately $20.4^{\circ} \mathrm{F}$, and August is the 


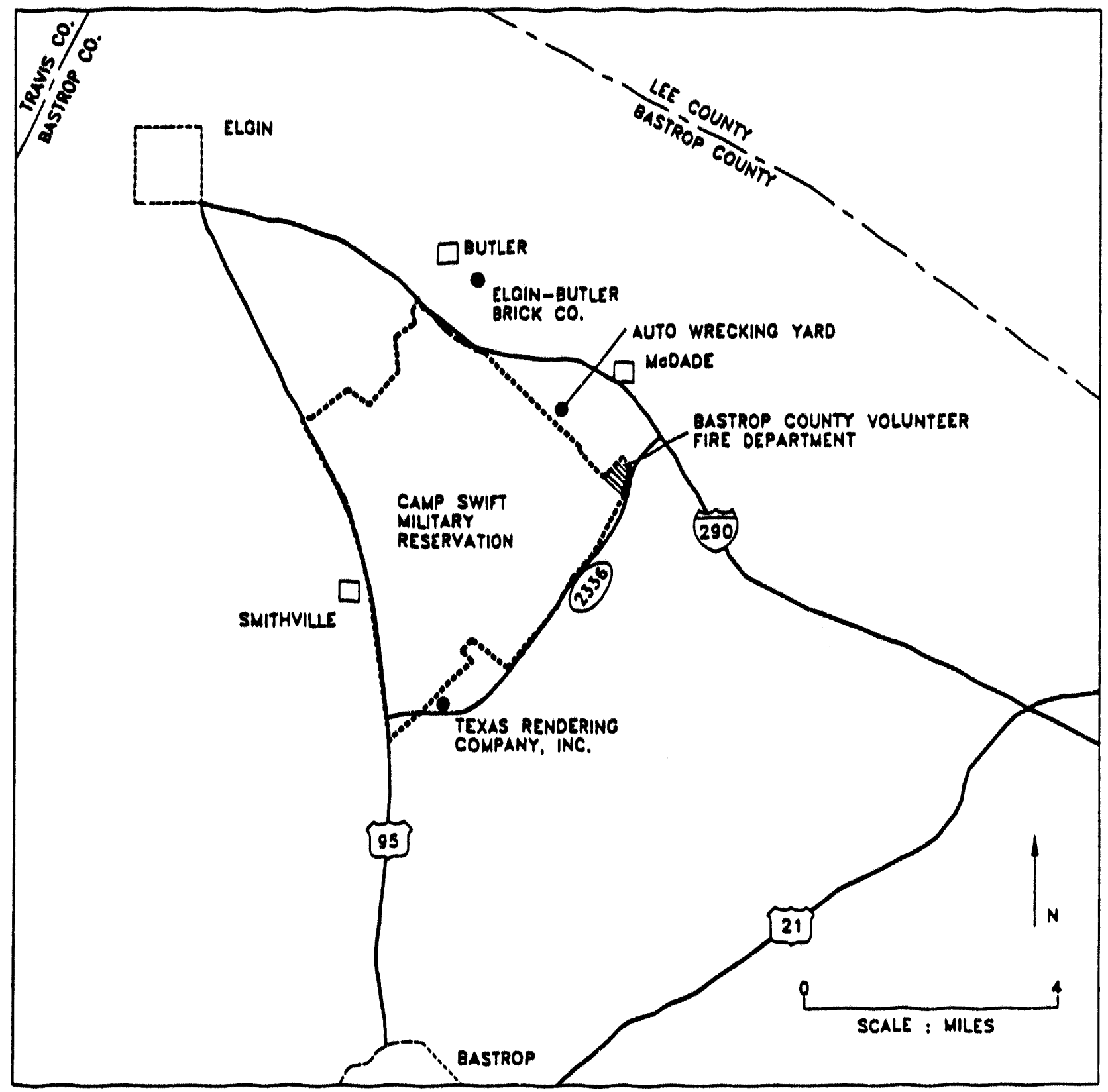

FIGURE 6 Camp Swift and Adjacent Property (Source: USGA 1982a-d) 
warmest, with an average high temperature of $104.2^{\circ} \mathrm{F}$. Typically 22 days each year have temperatures of freezing or below. Measurements taken during the period 1900-1983 at the National Weather Service monitoring station in Smithville (approximately 15 mi southeast of Camp Swift) indicate that precipitation averages about $36.7 \mathrm{in}$. annually, with measurable precipitation (0.01 in. or more) falling on at least 82 days each year (Larkin and Bomar 1983). May has the highest average monthly precipitation at approximately 4 in., and August has the lowest at just over $2 \mathrm{in}$. Snow is rare. Winds average about $9 \mathrm{mi} / \mathrm{hr}$ and are mainly from the south. Winds of $50 \mathrm{mi} / \mathrm{hr}$ occur about once every two years. Dispersion is generally good, with few periods of air stagnation. Airborne dust occurs infrequently (DOI 1982).

\subsubsection{Surface Water and Physiography}

The following sections describe the local and regional surface hydrology and physiography (Baker 1979; DOI 1980; Gaylord et al., 1985; Patterson 1963; Senger et al. 1984; USGS 1982a-d).

\subsubsection{Physiography}

Texas comprises four separate physiographic regions, as Figure 7 shows (Patterson 1963). These regions are (1) the Basin and Range province, (2) the Great Plains province, (3) the Central Lowland, and (4) the Coastal Plain. Camp Swift, in Bastrop County, is within the Coastal Plain province that occupies southeast Texas. The property is southeast of a geologic fault zone approximately 6-8 mi wide, known as the Balcones Fault Zone, that marks the transition between the Edwards Plateau in the western portion of Travis County (northwest of Bastrop County) and the Blackland Prairie in the eastern portion (Senger et al. 1984). The Coastal Plain province is an area of rolling plains extending east-southeast to the Gulf of Mexico at a rate of approximately $10 \mathrm{ft} / \mathrm{mi}$.

The topography of the Camp Swift area is gently rolling to undulating, and regionally the ground surface dips from northwest to southeast. Most of the TXARNG property is $450-500 \mathrm{ft}$ above mean sea level, although the site elevation in the western portion of the property at State Highway 95 is as much as $590 \mathrm{ft}$. Erosion has occurred to various degrees throughout Camp Swift. The most severe erosion began before the establishment of Camp Swift, when the land was used for farming and grazing. Formerly wooded areas were cleared and grasses stripped. Erosion 


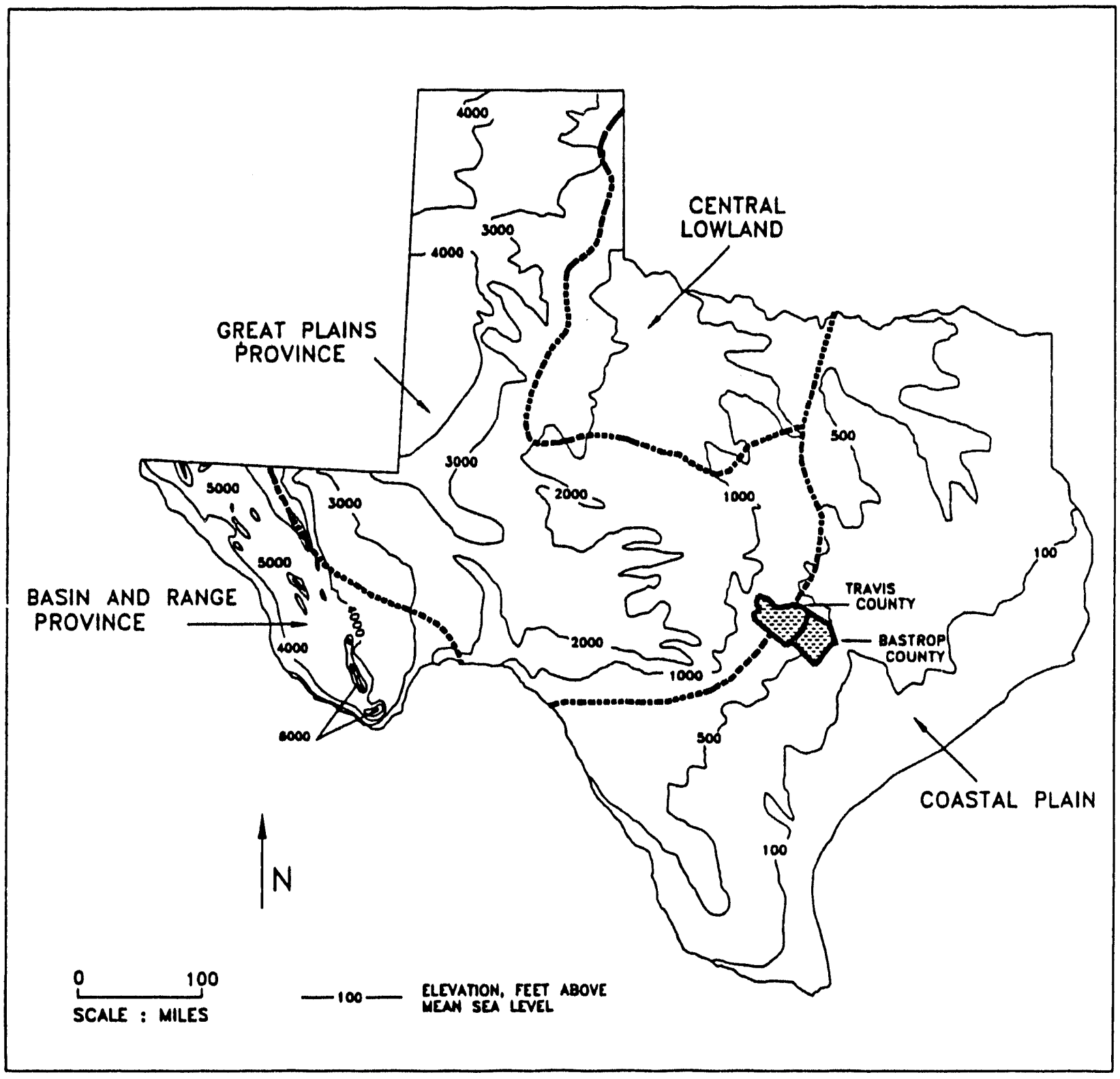

FIGURE 7 Major Physiographic Provinces of Texas (Source: Patterson 1963) 
of the edges of cleared uplands occurred and continues. In places streams have cut steep channels, with some severe gullying. Erosion has also occurred around the margins of old sand and clay pits, some of which contain standing water.

\subsubsection{Solls}

Two major soil associations predominate at the TXARNG property (Figure 8) (Baker 1979). These are the Patilo-Demona-Silstid association in the northern part of Camp Swift and the Axtell-Tabor association to the south.

The Patilo-Demona-Silstid association is present on sloping ridge tops and gently sloping to strongly sloping side slopes of upland areas. These soils have a sandy surface layer and moderately slowly permeable to moderately permeable lower layers. Patilo soils, occurring mostly on ridge tops and side slopes, have a surface layer of fine sand that is light brownish gray in the upper part and very pale brown in the lower part. The lower layers are acidic, mottled, sandy clay loam. Demona soils, found mostly on foot slopes and in drainageways, have a surface layer of loamy fine sand that is light brownish gray in the upper part and very pale brown in the lower part. The lower layers are acidic, mottled, sandy clay. Silstid soils, occurring mostly on foot slopes and in drainageways, have a surface layer of loamy fine sand that is light gray in the upper part and very pale brown in the lower part. The lower layers are acidic, mottled, sandy clay loam over clay loam. The hazard for erosion of these soils is slight to moderate. In the Camp Swift Reservation, Big Sandy Creek (Section 2.5.3.3) flows through an area dominated by the Patilo-Demona-Silstid group.

The Axtell-Tabor association is present on stream terraces and uplands and has typically been deposited in large, irregularly shaped areas. These nearly level to strongly sloping soils are characterized by a loamy surface layer and very slowly permeable lower layers. Axtell soils are primarily gently sloping and are on ridge tops and steeper side slopes. These soils have a surface layer of fine sandy loam that is brown in the upper part and pale brown in the lower part. The lower layers are acidic, mottled clay or sandy clay. Tabor soils are nearly level to gently sloping and are on ridge tops and foot slopes and in drainageways. These soils have a surface layer of fine sandy loam that is grayish brown in the upper part and pale brown in the lower part. The lower layers are acidic, mottled clay. The hazard of erosion for the Axtell-Tabor association is moderate to significant, and the formation of gullies is common. The Dogwood Creek and McLaughlin Creek drainage basins (Section 2.5.3.3) are in the area of Axtell-Tabor soils. 


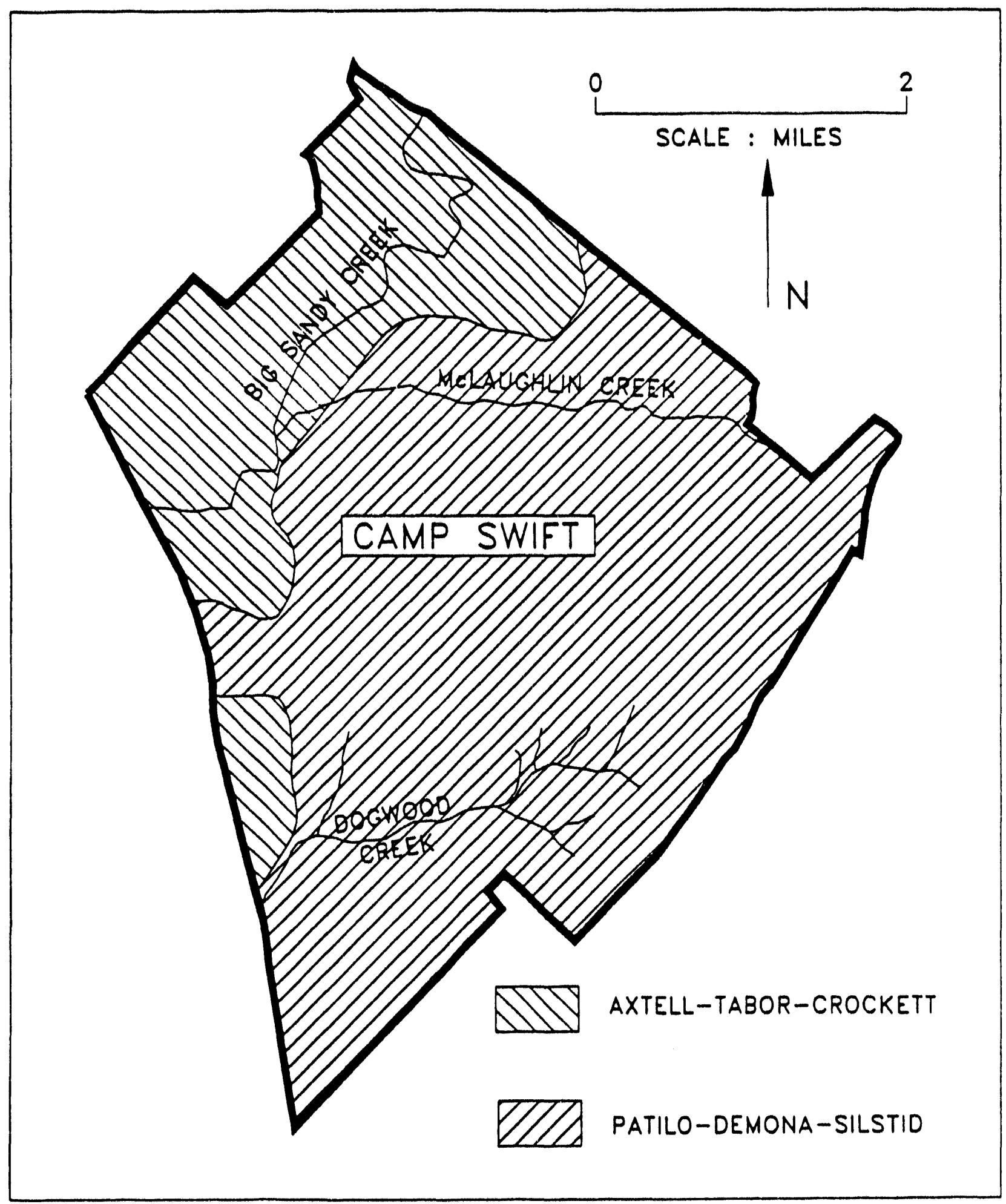

FIGURE 8 Major Soil Associations Present at Camp Swift Military Reservation (Source: Baker 1979) 


\subsubsection{Surface Hydrology}

Camp Swift is in the basin of the Colorado River, which flows through Bastrop County from northwest to southeast about 6 mi south of the TXARNG property (Gaylord et al. 1985; DOI 1980). As Figure 9 shows, Camp Swift is drained by Big Sandy Creek, McLaughlin Creek, and Dogwood Creek and to a minor extent by Piney Creek. Big Sandy Creek flows through the northwestern portion of the TXARNG property toward the Colorado River. The drainage area of Big Sandy Creek where it enters Camp Swift on the north is $60.5 \mathrm{mi}^{2}$. This drainage area extends northward into Williamson County and Lee County and includes the small town of Butler. Big Sandy Creek flows into the Colorado River approximately $6 \mathrm{mi}$ southwest of the Camp Swift boundary. Within the TXARNG property, Dogwood Creek and McLaughlin Creek are tributaries to Big Sandy Creek. McLaughlin Creek has a drainage area of $10.9 \mathrm{mi}^{2}$, including the city of McDade. Almost half of the McLaughlin Creek drainage basin is within Camp Swift. Dogwood Creek has a drainage area of $5.5 \mathrm{mi}^{2}$, almost totally within Camp Swift. Dogwood Creek is undeveloped. A minor portion of the TXARNG property (a total of $0.15 \mathrm{mi}^{2}$ in the southeastern portion of the property) drains into natural tributaries of Piney Creek.

The major drainage areas within Camp Swift slope southwesterly and westerly from altitudes of more than $500 \mathrm{ft}$ above mean sea level near the headwaters of McLaughlin Creek and Dogwood Creek to an altitude of $400 \mathrm{ft}$ where Big Sandy Creek crosses State Highway 95. Big Sandy Creek is a perennial stream with an average discharge estimated at $20 \mathrm{ft}^{3}$ per second $\left(\mathrm{ft}^{3} / \mathrm{s}\right)$. McLaughlin Creek and Dogwood Creek are intermittent streams with an average discharge estimated at $4.3 \mathrm{ft}^{3} / \mathrm{s}$ and $2.3 \mathrm{ft} 3 / \mathrm{s}$, respectively. The estimated 100-year floods for these streams are $20,800 \mathrm{ft}^{3} / \mathrm{s}, 6,800 \mathrm{ft}^{3} / \mathrm{s}$, and $4,500 \mathrm{ft}^{3} / \mathrm{s}$, respectively. As Figure 10 shows, flood hazard areas within Camp Swift are mostly confined to the channel areas of McLaughlin Creek and Dogwood Creek (DOI 1980). No areas are subject to flash flooding (TXARNG 1988a).

Lake Bastrop, south of the TXARNG property, is an artificially created lake used for cooling water supply and recreation, but not as a municipal water supply. Approximately 9.6 million gallons of water per day are withdrawn from Lake Bastrop and used in a nearby steam-powered electric-generating plant. Except for consum." /e losses, the water is returned to the lake (Gaylord et al. 1985). 


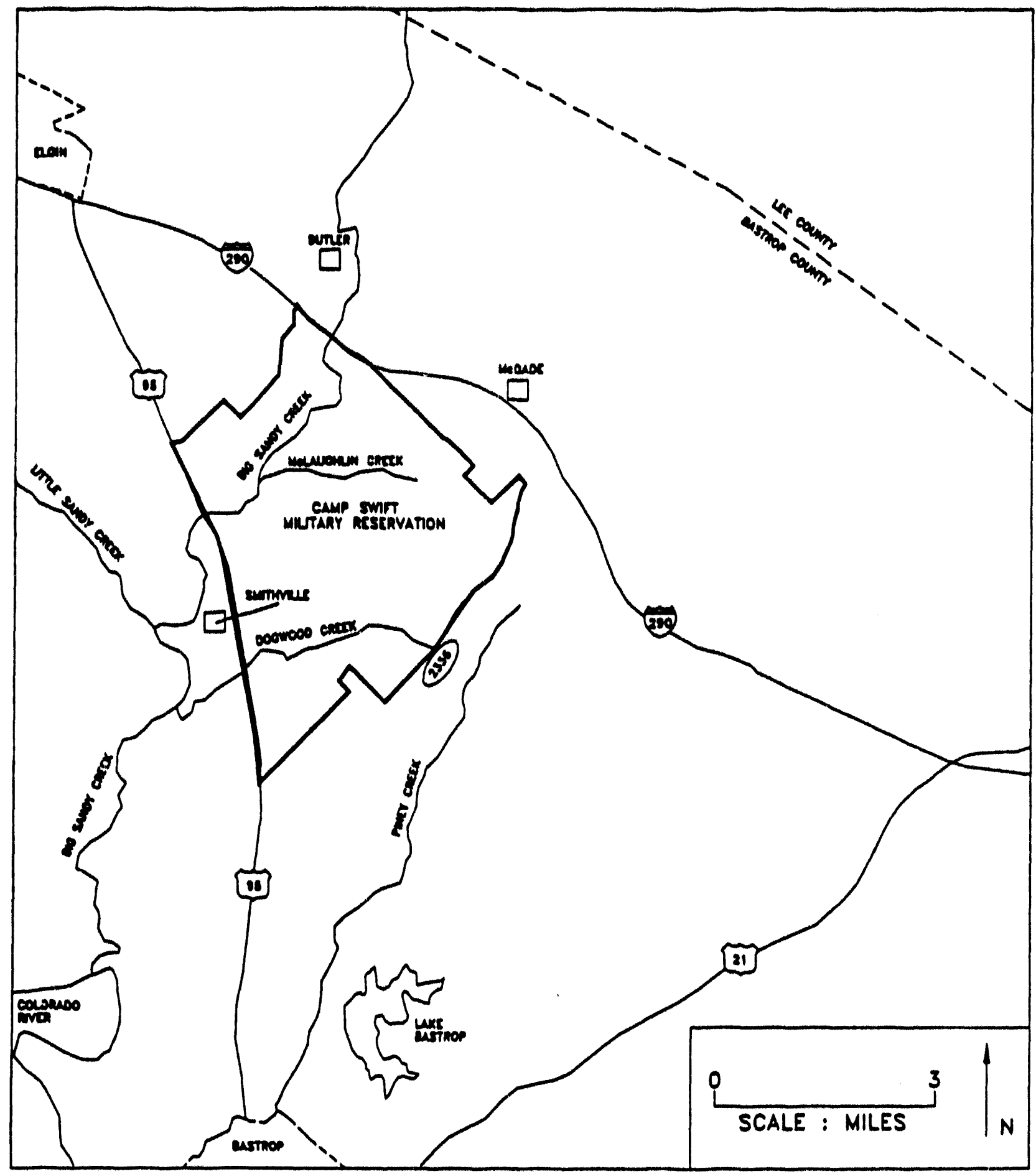

FIGURE 9 Location of Regional Surface Waters (Source: Gaylord et al. 1985) 


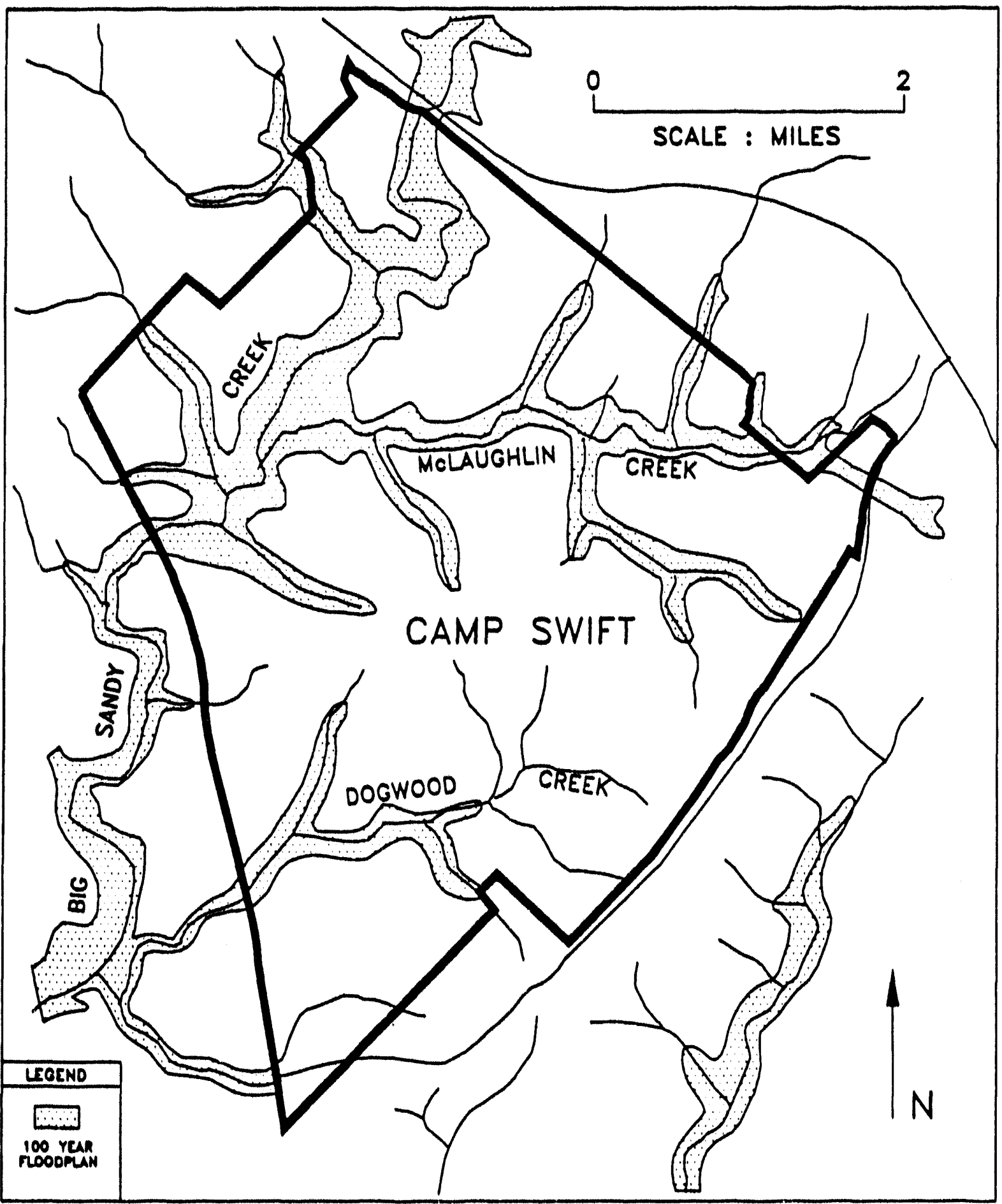

FIGURE 10 Flood Hazard Areas (100 year) within Camp Swift (Source: DOI 1980) 


\subsubsection{Groundwater and Hydrogeology}

The following sections describe the regional and local geology and groundwater (Brune 1983; DOI 1980, 1982; Follett 1970; Gaylord et al. 1985; Thorkildsen and Price 1991).

\subsubsection{Regional Ceology}

The geologic history of central Texas, which includes Bastrop County and the area southeast tow ard the Gulf of Mexico, is complex (Brune 1983). During Precambrian time the sea extended northward into the region, depositing limestone, sandstone, carbonaceous shales, and other marine sediments. This sedimentary basin existed during most of the Paleozoic Era. Deposition in the basin was terminated during Pennsylvanian time when the area west of Bastrop County was raised above sea level. Known as the Llano uplift, this folding caused regional tilting to the west, and most of Texas became dry land as the sea retreated south toward the Gulf. Then, at the beginning of the Cretaceous period, the sea advanced again from the east and south, eventually covering all of central Texas. The Cretaceous period was marked by a series of regressions and transgressions (lessening in extent overall) resulting in the deposition of sequences of limestone, sandstone, and shale, as shown in Figure 11 (Follett 1970).

Geologic formations penetrated by water wells in Bastrop County, ranging in age from youngest to oldest, are as follows: the alluvium and associated gravel of Quaternary age; the Yegua Formation, the Cook Mountain Formation, Sparta Sand, Weches Greensand, Queen City Sand, Reklaw Formation, Carrizo Sand, the Wilcox Group, and the Midway Group of Tertiary age and the Navarro Group of Cretaceous age. Alluvium, consisting principally of sand with small gravel and disconnected lenses of clay and silt, is deposited along the Colorado River to a maximum depth of about $50 \mathrm{ft}$. Uvalde Gravel (not shown in Figure 11), ranging in thickness from a few inches to nearly $4 \mathrm{ft}$, caps some of the higher ridges in the county. The Yegua, a continental deposit about $200 \mathrm{ft}$ thick, consists of layers of medium to fine sand, silt, sandy and carbonaceous clay, and lignite. The most recent encroachment of the sea during the Cretaceous age resulted in the deposition of the Yegua only along the southeastern portion of the county. Deposited previously was the Cook Mountain Formation, a marine deposit with a maximum thickness of $370 \mathrm{ft}$ consisting of clay with a few thin lenses of sand, sandstone, limestone, and gypsum. The fine to medium, stratified, lightly cemented Sparta Sand bed has a maximum thickness of $90 \mathrm{ft}$ and dips southeastward at about $100 \mathrm{ft} / \mathrm{mi}$. Weches Greensand, composed of 


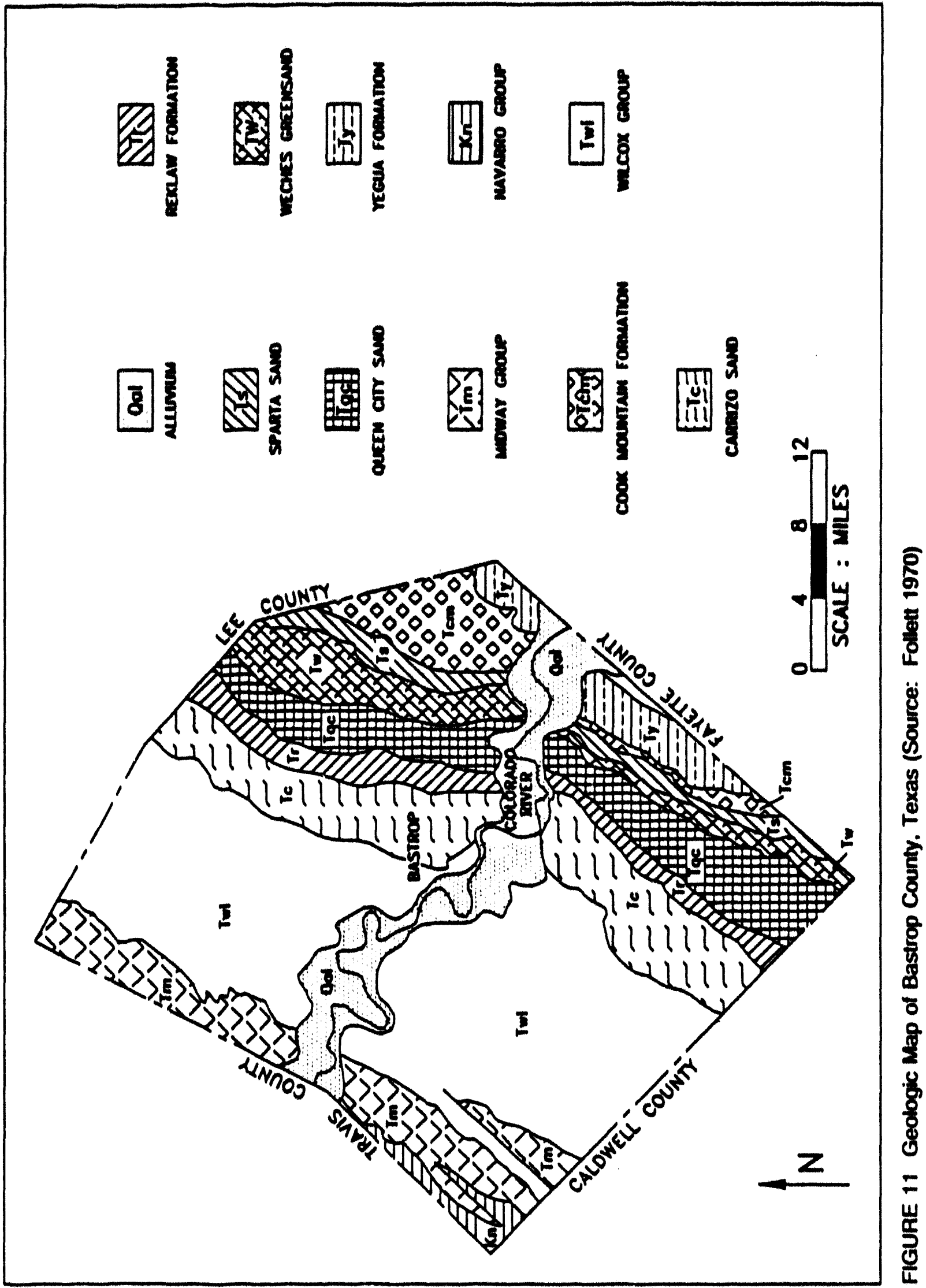


about $100 \mathrm{ft}$ of brown, iron-bearing clay and sand, crops out in a band $1.3 \mathrm{mi}$ wide across the southeastern part of Bastrop County. Queen City Sand, with a maximum thickness of about $535 \mathrm{ft}$ and dipping southeastward at about $120 \mathrm{ft} / \mathrm{mi}$, is composed of light gray, fine to medlum sand (about 40\%); clay; and lenses of iron-bearing conglomerate. The two-part Reklaw Formation has a maximum thickness of about $400 \mathrm{ft}$, dipping southeastward at about $130-140 \mathrm{f} / \mathrm{mi}$. The upper Reklaw consists chiefly of clay and a few thin beds of sandstone, whereas the lower Reklaw consists principally of glauconitic, buff-colored sand and silt. The white, loose Carrizo Sand has a maximum thickness of about $375 \mathrm{ft}$ and crops out in a belt $2.4 \mathrm{mi}$ wide across central Bastrop County. The Wilcox Group underlies the Carrizo Sand, cropping out across the north-central part of the county in a belt $9.15 \mathrm{mi}$ wide. The Wilcox consists chiefly of fine to coarse sund (about $40 \%$ ) and lesser amounts of clay, sandy clay, sundstone, silty shale, and lenses of lignite. The full thickness of the Wilcox ranges from about $1.400 \mathrm{ft}$ to $2,600 \mathrm{ft}$, thickening toward the southeastern portion of the county. The oldest deposit of Tertiary age is the Midway Group. which extends toward the northwestern county line. It consists of clay, silt, glauconitic sand with thin beds of limestone, and sandstone and has a maximum thickness of about $800 \mathrm{ft}$. The Navarro Group, of Cretaceous age and composed mostly of clay and silt with lenses of bluish sandstone. is exposed only in the western corner of Bastrop County. Sand and sandstone of the Pearsall Formation are found below 3,000 $\mathrm{ft}$ in Bastrop County (Follett 1970).

\subsubsection{Looal Geology}

Deposition of the Wilcox Group sediments during the early Tertiary period extended northeastward into central Texas to cover the Camp Swift region. Figure 12 provides a generalized geologic cross section in the vicinity of the TXARNG property. During the Wilcox time, the aerial extent of the fluvial and deltaic deposition lessened. The Wilcox Group is divided into three formations, which (from oldest to youngest) are the Hooper, Simsboro, and Calvert Bluff formations (DOI 1982).

The Calvert Bluff Formation underlies most of Camp Swift. Outercps of the formution are few, however, because it is generally covered by several feet of soil. The sand formation is stratified. Between channel sands, interchannel fure-grained sand and mud deposits occur to a total depth of 1,000 ft. During Wilcox time when this depositional system was active, large amounts of organic material also accumulated in the interchunnel areas, and these eventually formed modern lignite deposits. At least five distinct lignite-bearing strata (4-12 ft thick) are present throughout 


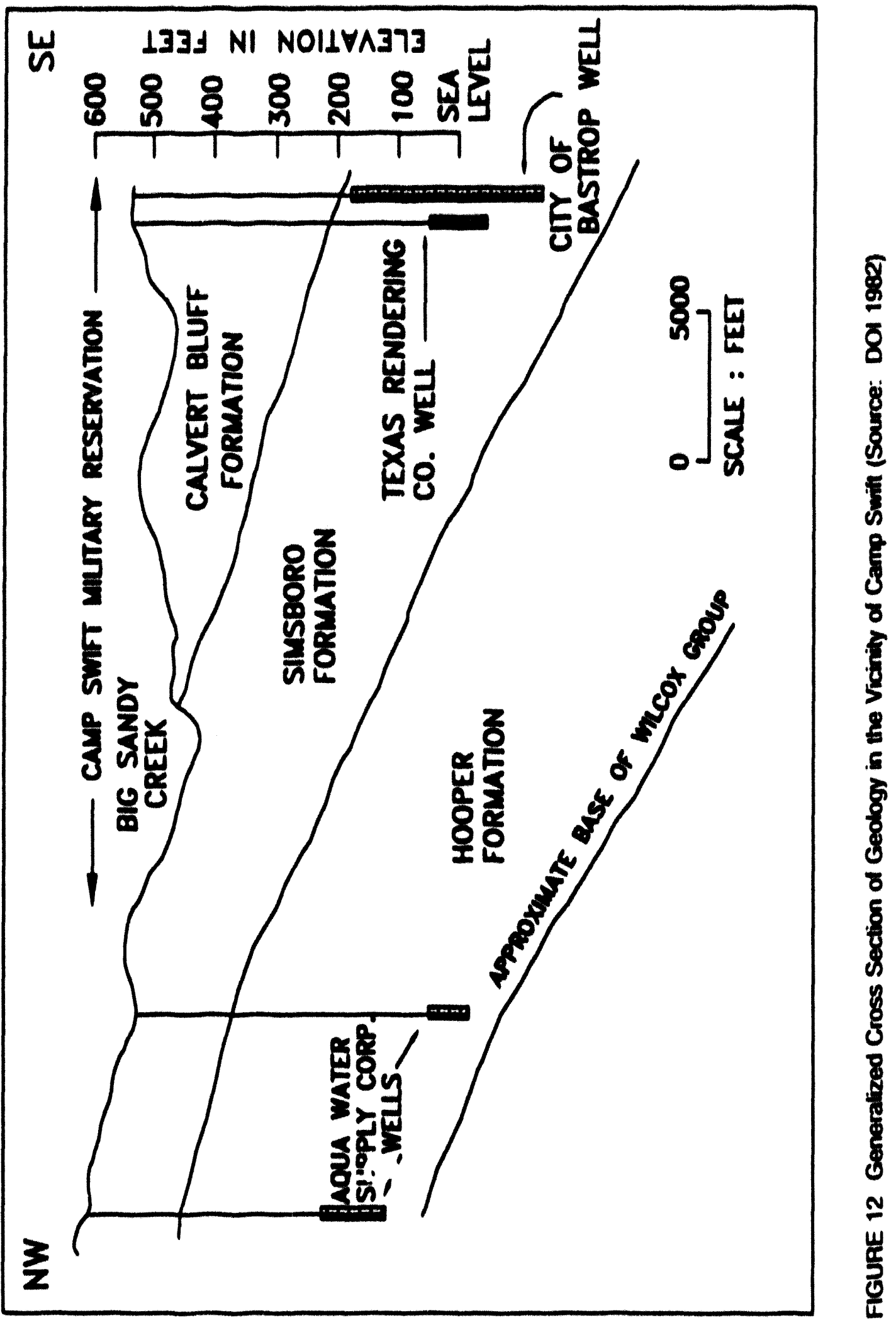


the region (DOI 1980). Within Camp Swift, three of the five strata contain an estimated 70 million 1090 million metric tons of lignite recoverable by surface mining methods. Two to three of these lignite units were offered for lease by the Bureau of Land Management, although lease negotiations were never finalized (DOI 1980, 1982). The lignite beds of interest are in the lower portion of the Calvert Bluff Formation, about $60.70 \mathrm{ft}$ above the top of the lower Simsboro Formation.

The Simsboro Formation crops out west and north of Big Sandy Creek. Underlying the Calvert Bluff Formation, the Simsboro ranges in thickness from $0 \mathrm{ft}$ to more than $800 \mathrm{ft}$ toward the southeust. The Simsboro sediment is composed primarily of fine- to coarse-grained, light gray sand with relatively small amounts of clay, mudstone, and mudstone conglomerate. The sund is hardened in places.

The Hooper Formation underlies the Simsboro but first crops out several miles west of Camp Swift. It is about $500 \mathrm{ft}$ thick in the Camp Swift area and consists of mudstone, sund, and sandstone with a few beds of lignite. The sand and sandstone beds are very fine to medium grained. The sund is usually well sorted and rounded.

Well AT-58-54-507 is locuted approximately I mi south of the TXARNG property. This city of Bastrop public supply well was one of several wells installed to provide water to Camp Swift when it was constructed as a U.S. Army training center. Table 3 is the driller's log of Well AT-58-54-507, providing a description of the local geology to the well depth of $672 \mathrm{ft}$.

\subsubsection{Reglonal Oroundwator}

The principal water-bearing unit in the region is the Carrizo-Wilcox aquifer, consisting of the Carrizo Formation and the Wilcox Group (Thorkildsen and Price 1991). The Hooper Formation, underlying the Simsboro, Calven Bluff, and Carrizo formations, is the least productive water-bearing unit in the Wilcox Group. The gross thickness of the Hooper Formation can exceed $1.300 \mathrm{ft}$ in the deep subsurface southeast of the TXARNG property, toward the Gulf. However, groundwater development in the Hooper generally occurs in shallower areas near its outcrop. where its thickness is less than $500 \mathrm{ft}$. The Simsboro is the dominant water-beuring unit in the Wilcox Group, yielding as much as $1,000-1,200 \mathrm{gal} / \mathrm{min}$. As with the Hooper Formation, development occurs mainly on its outcrop, although some of the most productive Simsboro wells are completed (outside the study area) at depths in excess of $2,000 \mathrm{ft}$ (Thorkildsen und Price 
TABLE 3 Driller's Log of Well YD.58-54-507, near the Camp Swift Property

\begin{tabular}{|c|c|c|}
\hline Description of Soll of Rock & $\begin{array}{l}\text { Thickness } \\
\text { (It) }\end{array}$ & $\begin{array}{c}\text { Depth } \\
\text { (It) }\end{array}$ \\
\hline 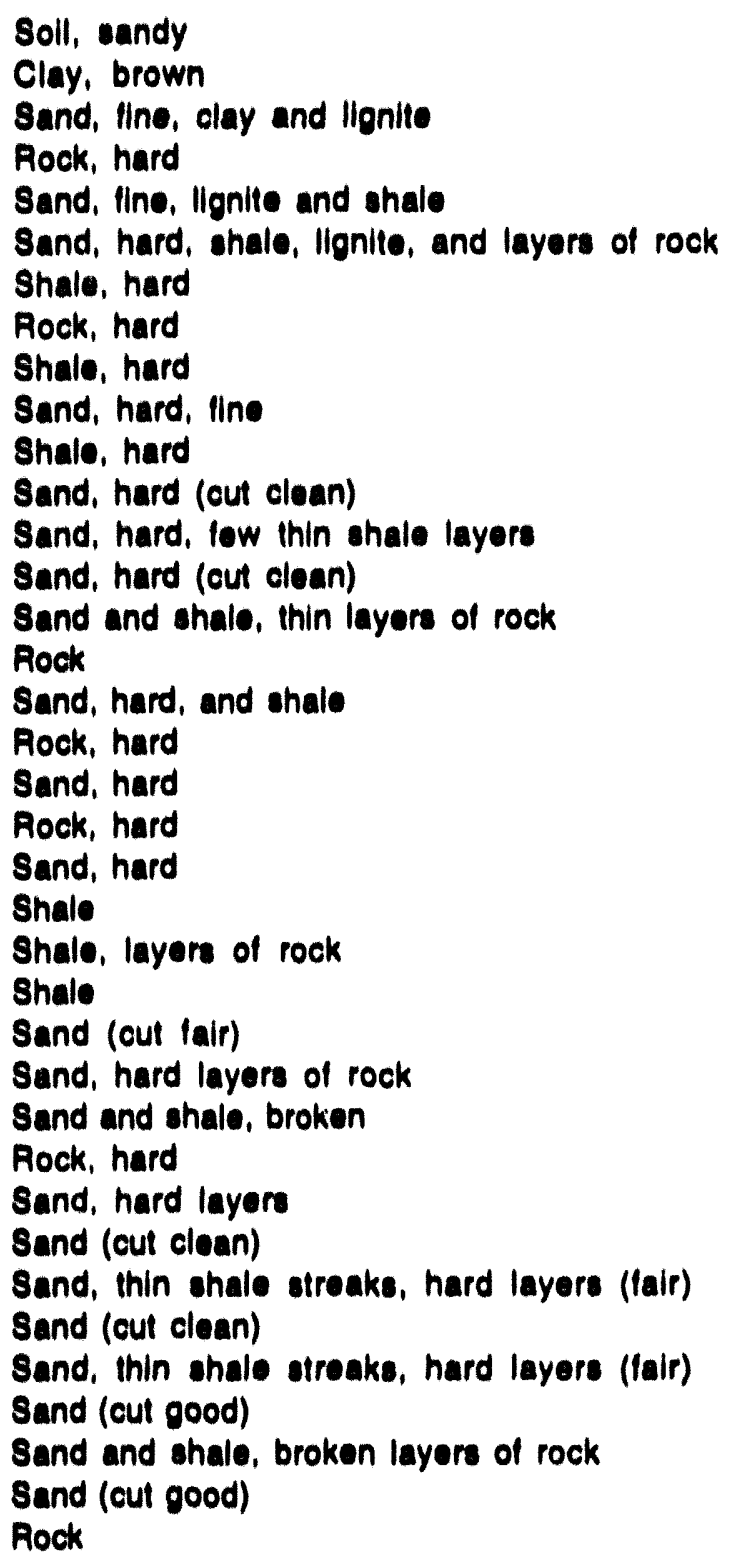 & $\begin{array}{r}2 \\
10 \\
18 \\
1 \\
26 \\
48 \\
35 \\
3 \\
23 \\
15 \\
22 \\
68 \\
22 \\
38 \\
6 \\
2 \\
13 \\
3 \\
14 \\
4 \\
23 \\
9 \\
4 \\
33 \\
14 \\
5 \\
20 \\
7 \\
10 \\
45 \\
14 \\
35 \\
26 \\
48 \\
15 \\
18 \\
4\end{array}$ & $\begin{array}{r}2 \\
12 \\
30 \\
31 \\
57 \\
105 \\
140 \\
143 \\
166 \\
181 \\
203 \\
272 \\
294 \\
330 \\
336 \\
338 \\
351 \\
354 \\
368 \\
372 \\
395 \\
404 \\
408 \\
411 \\
425 \\
430 \\
450 \\
457 \\
467 \\
512 \\
526 \\
561 \\
587 \\
635 \\
650 \\
668 \\
672\end{array}$ \\
\hline
\end{tabular}

- Driller: Layne-Toxas Co.

Source: Folletl (1970). 
1991). Groundwater in the Calvert Bluff Formation is available from scattered, lenticular sands of the ancient tributary channels. The orientation of most of these channels is from northwest to southeast, giving the water deeper within the zone of saturation its dominant southeasterly movement. The orientation of other channels is multidirectional. The interchannel clayey deposits contain very little water and act as an aquitard. Yields range from small (less than $1 \mathrm{gal} / \mathrm{min}$ ) to moderate (several tens of gallons per minute).

Recharge to the Carrizo-Wilcox occurs (1) in the outcrop belt, (2) by infiltration of stream flow, and (3) through interformational leakage. Most recharge to the Carrizo-W'ilcox occurs in the outcrop belt, and water moves downdip to the southeast (DOI 1982, Gaylord et al. 1985). Figure 13 shows the locations of aquifer outcrops near Camp Swift. Figure 14 depicts the source, recharge, and movement of groundwater. Water in the outcrop belt is under water table conditions, but artesian conditions exist within the lower formations of the Wilcox Group, where the water-bearing strata are confined by overlying, less permeable strata. This pattern is most evident at the base of the Calvert Bluff Formation below the lowest lignite seam. The potentiometric surface occurs below the top of the aquifer in the outcrop north of Camp Swift and slopes to the southeast. The rate of groundwater movement is about 10-100 ft/yr.

Recharge of the Simsboro and Calvert Bluff formations may also result from infiltration from the streams that flow over the outcrop of the aquifers. Where the water table is below the water level in the stream, as at Dogwood Creek on Camp Swift, water percolates through the stream channel and into the aquifer. The rate of this percolation depends on the permeability of the material below the stream channel.

Leakage from one geologic formation to another is a minor source of recharge to the aquifers in the vicinity of Camp Swift. The interformational recharge through the Calvert Bluff Formation to the Simsboro and Hooper formations below is minimal because of the small vertical hydraulic conductivity of the confining beds of lignite and clay near the base of the Calvert Bluff. Geohydrologic testing has been performed at Camp Swift by the U.S. Geological Survey to determine the geohydrologic characteristics of the Calvert Bluff and Simsboro formations (Gaylord et al. 1985). Monitoring of water levels in wells during extended periods of pumping and recovery revealed no change in water levels in wells drilled to the Simsboro, leading to the conclusion that the lignite and other tight beds of fine sand or clay present in the Calvert Bluff Formation are effective confining beds between the two formations. 


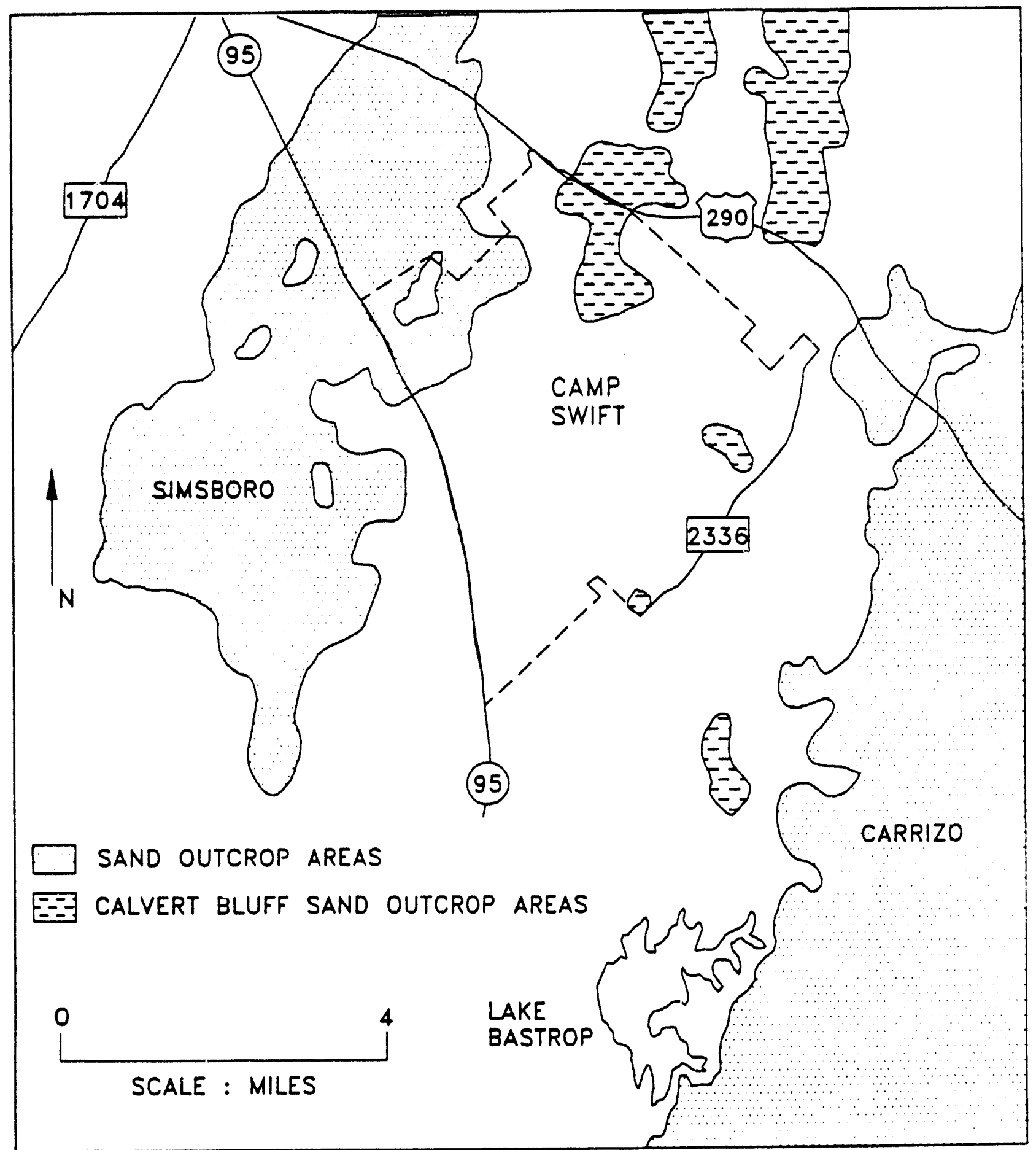

FIGURE 13 Locations of Aquifer Outcrops in the Vicinity of Camp Swift (Source: DOI 1982) 


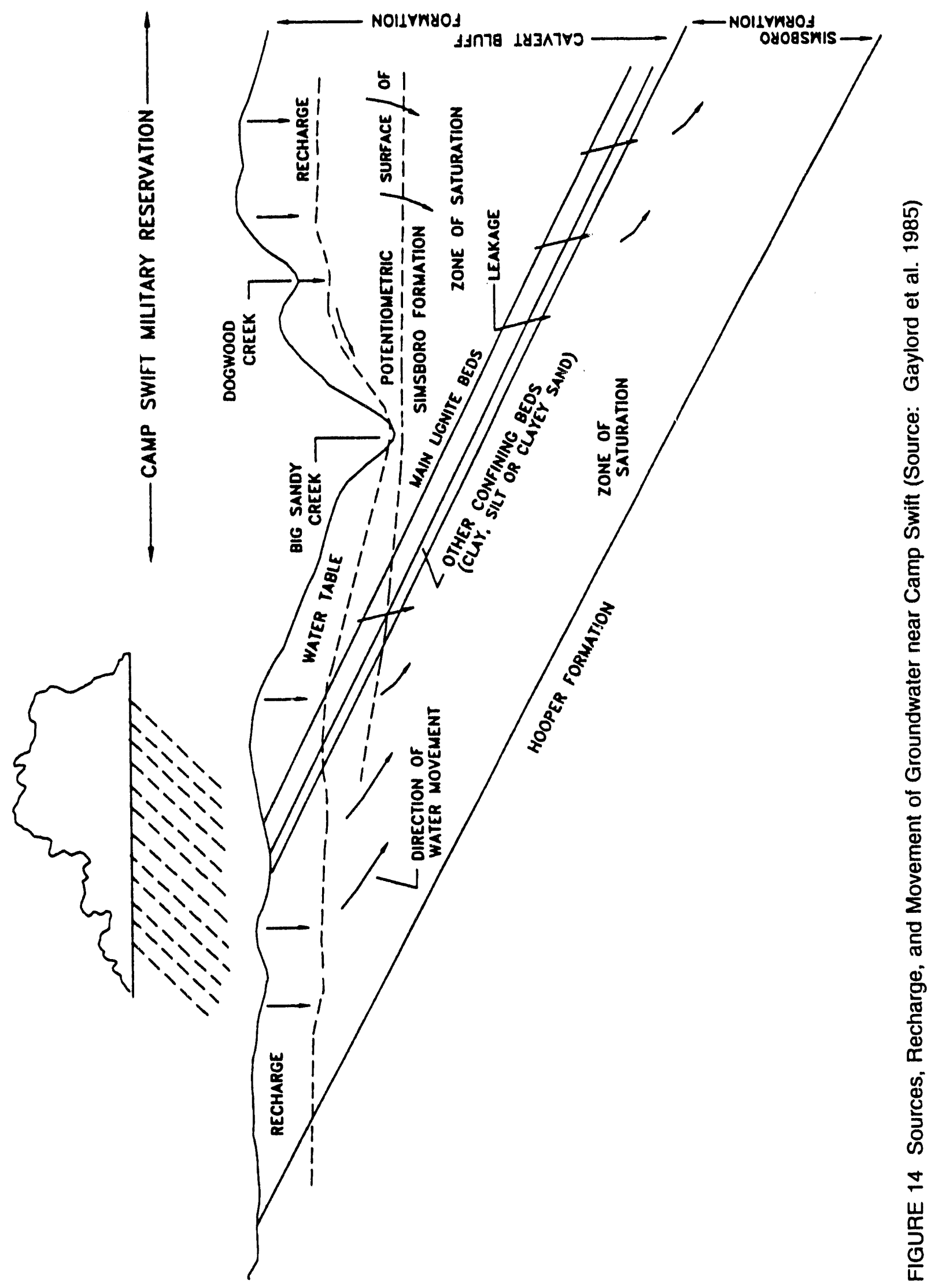




\subsubsection{Local Groundwater}

Six major water users are currently in the vicinity of Camp Swift: the cities of Bastrop, Elgin, and McDade; the Aqua Water Company; the Texas Rendering Company; and the ElginButler Brick Company. All of the wells serving these users are located in the Simsboro Formation except those for the Aqua Water Company, which are completed in the Hooper Formation. The locations of the wells of these six major water users are shown in Figure 15.

In areas outside the boundaries of the municipal water systems, private wells have been installed to provide water for domestic use and for livestock and small irrigation plots. More than 200 private wells have been registered with the Texas Water Commission since the 1930s. Undoubtedly, use of a number of these private wells was discontinued as nearby municipal water supply distribution networks were extended, but many are still in operation. Figure 16 shows the numbers of registered wells in the vicinity of Camp Swift as they are allocated by the Texas Water Commission grid-numbering system. Table 4 describes the registered wells in the vicinity of Camp Swift.

Although regional groundwater movement is to the southeast, localized pumping for the six municipal and industrial water users in the vicinity has caused cones of depression east of Elgin and near the south corner of Camp Swift. Water within the Simsboro Formation moves into these depressions from virtually all directions. Within Camp Swift, shallow groundwater movement is toward Big Sandy Creek and Dogwond Creek. A shallow groundwater divide occurs along the southeastern boundary of the reservation (at Farm-to-Market Road 2336), where a land surface divide is located. North of the divide, shallow groundwater moves northwesterly toward Big Sandy Creek and Dogwood Creek. South of the divide, shallow groundwater moves southeasterly toward Piney Creek (Gaylord et al. 1985).

\subsubsection{Sensitive Environments}

Camp Swift is located in the ecotone hetween the western prairie and the southeastern forest. Vegetation within Camp Swift can be characterized as (1) upland forest, (2) stream side, and (3) grassland. The upland forest area of the camp is dominated by post oak and red cedar. Stream side vegetation occurs along Big Sandy, McLaughlin, and Dogwood creeks. Trees in these areas include post oak, black willow, water oak, American elm, cottonwood, hackberry, red 


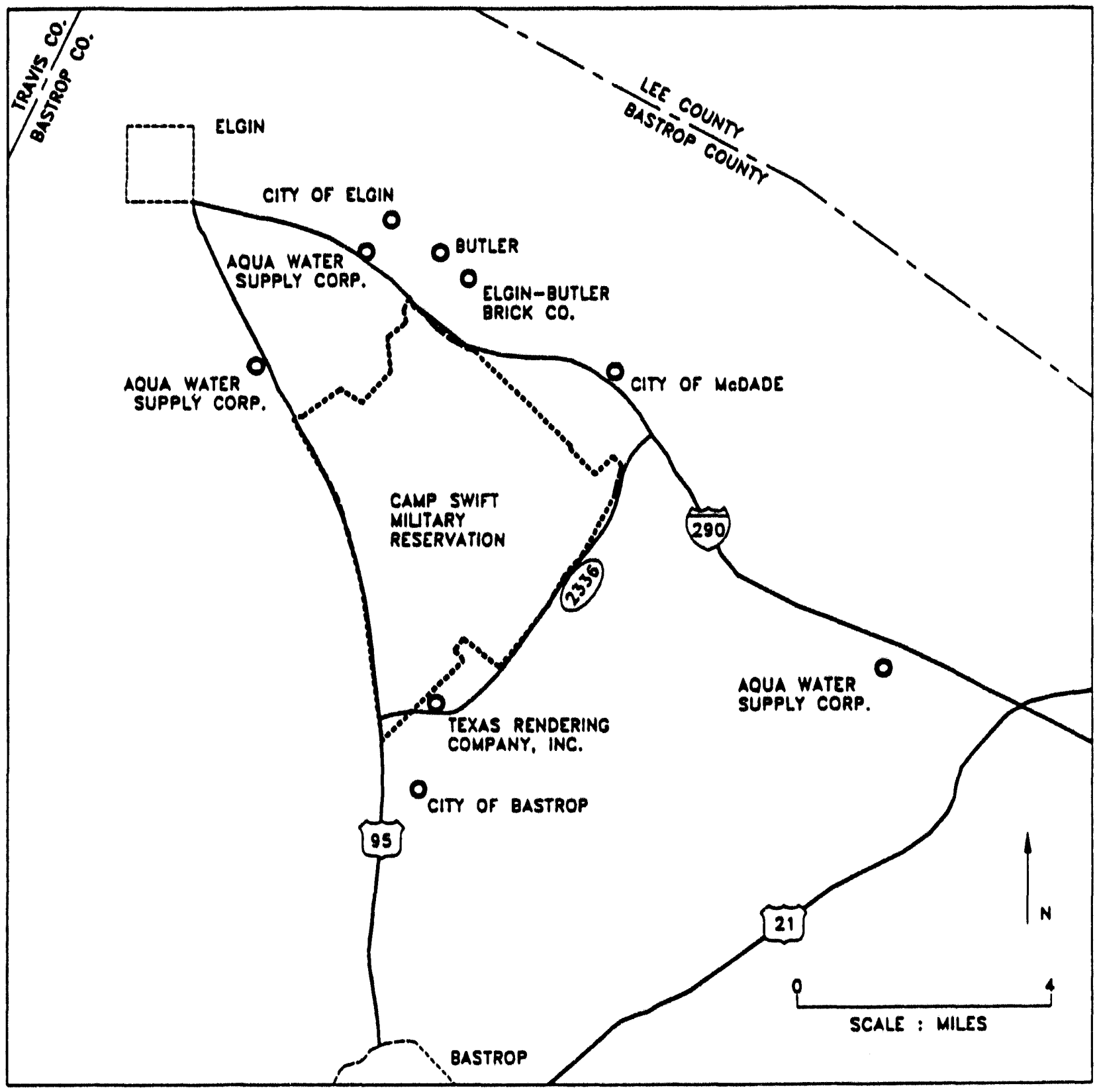

FIGURE 15 Well Locations of Major Water Users in the Vicinity of Camp Swift (Source: Gaylord ot al. 1985) 


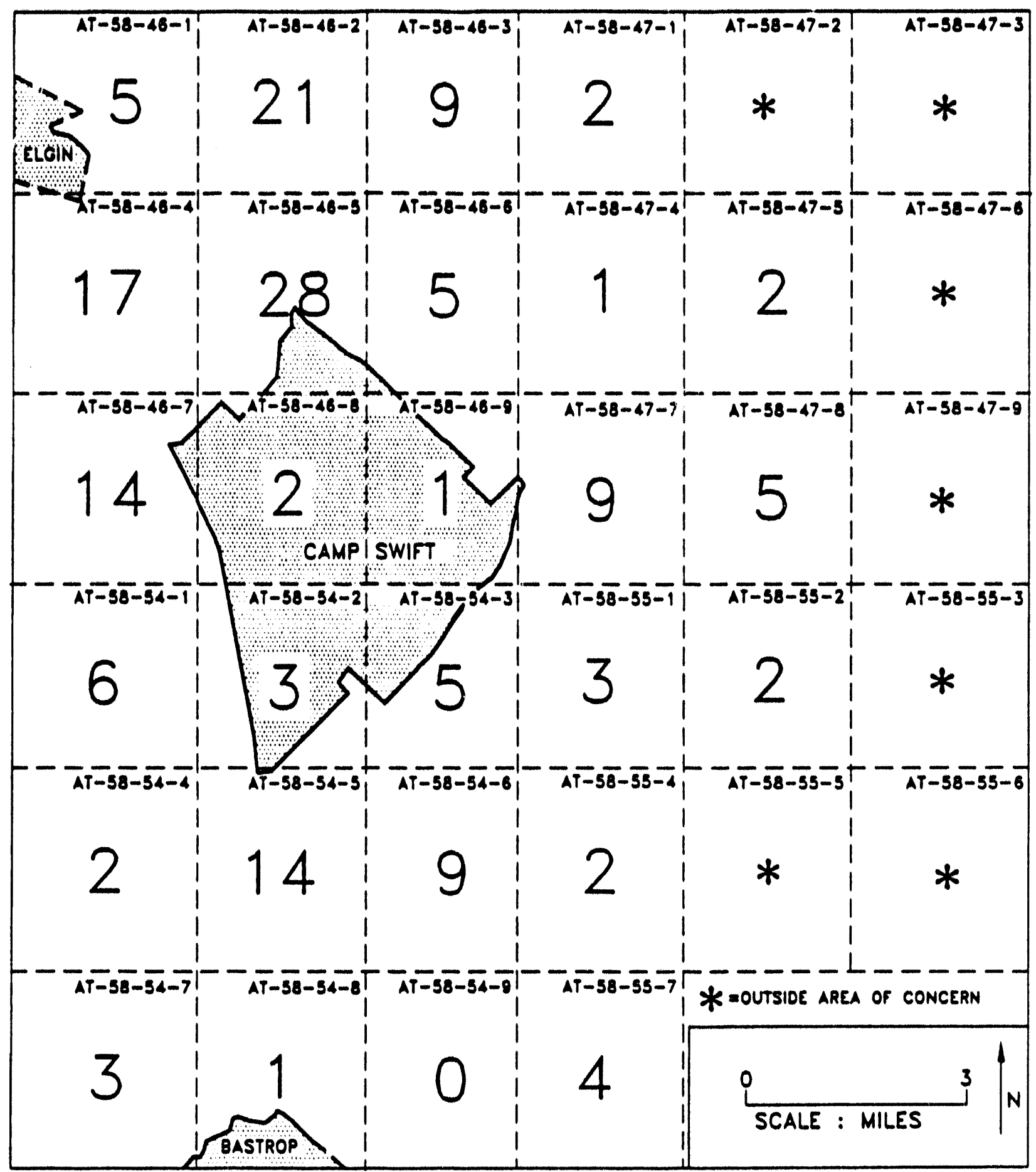

FIGURE 16 Number of Registered Wells Located in the Texas Water Commission's WellNumbering Grids near Camp Swift (Source: TDWR 1993) 


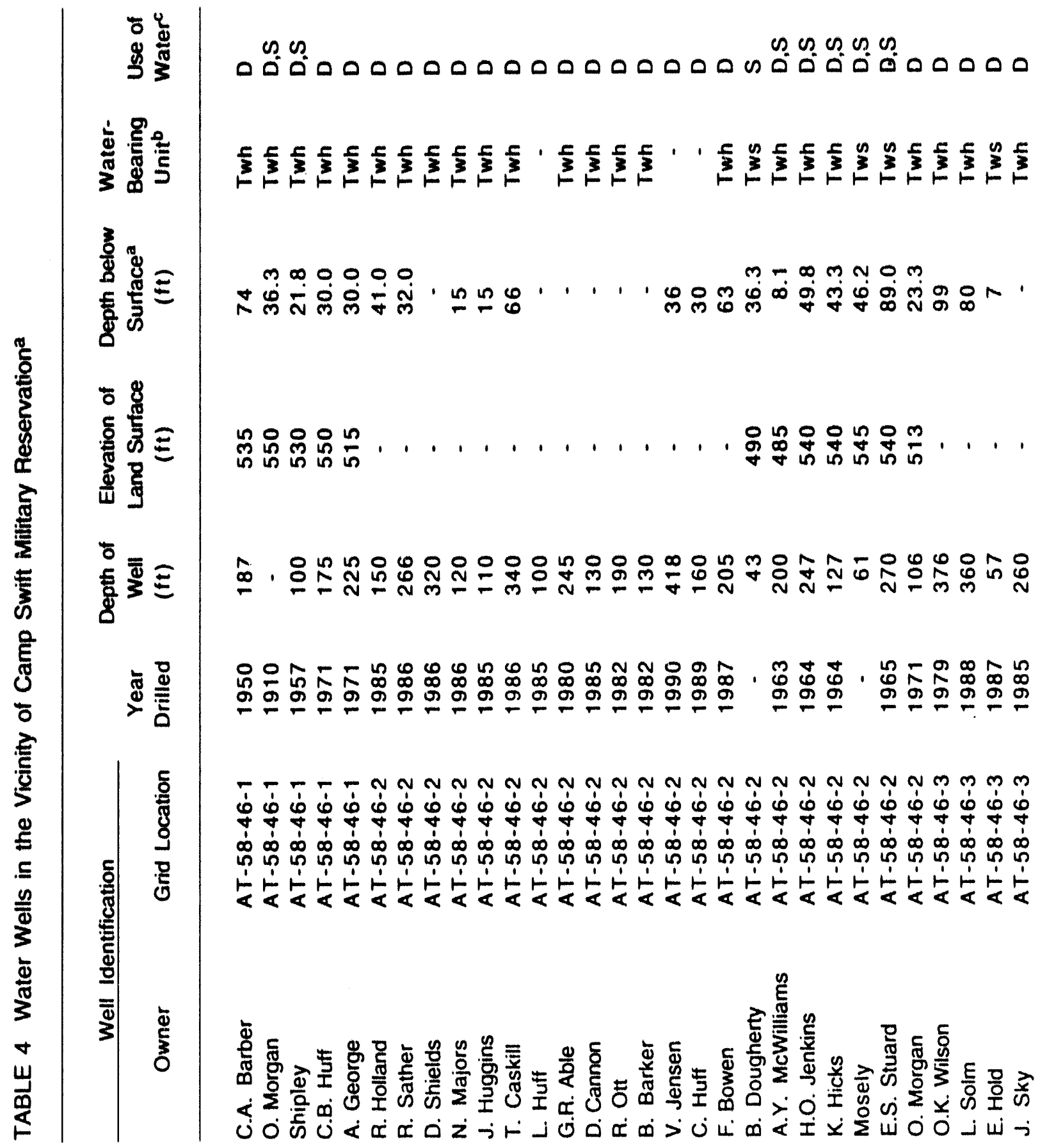




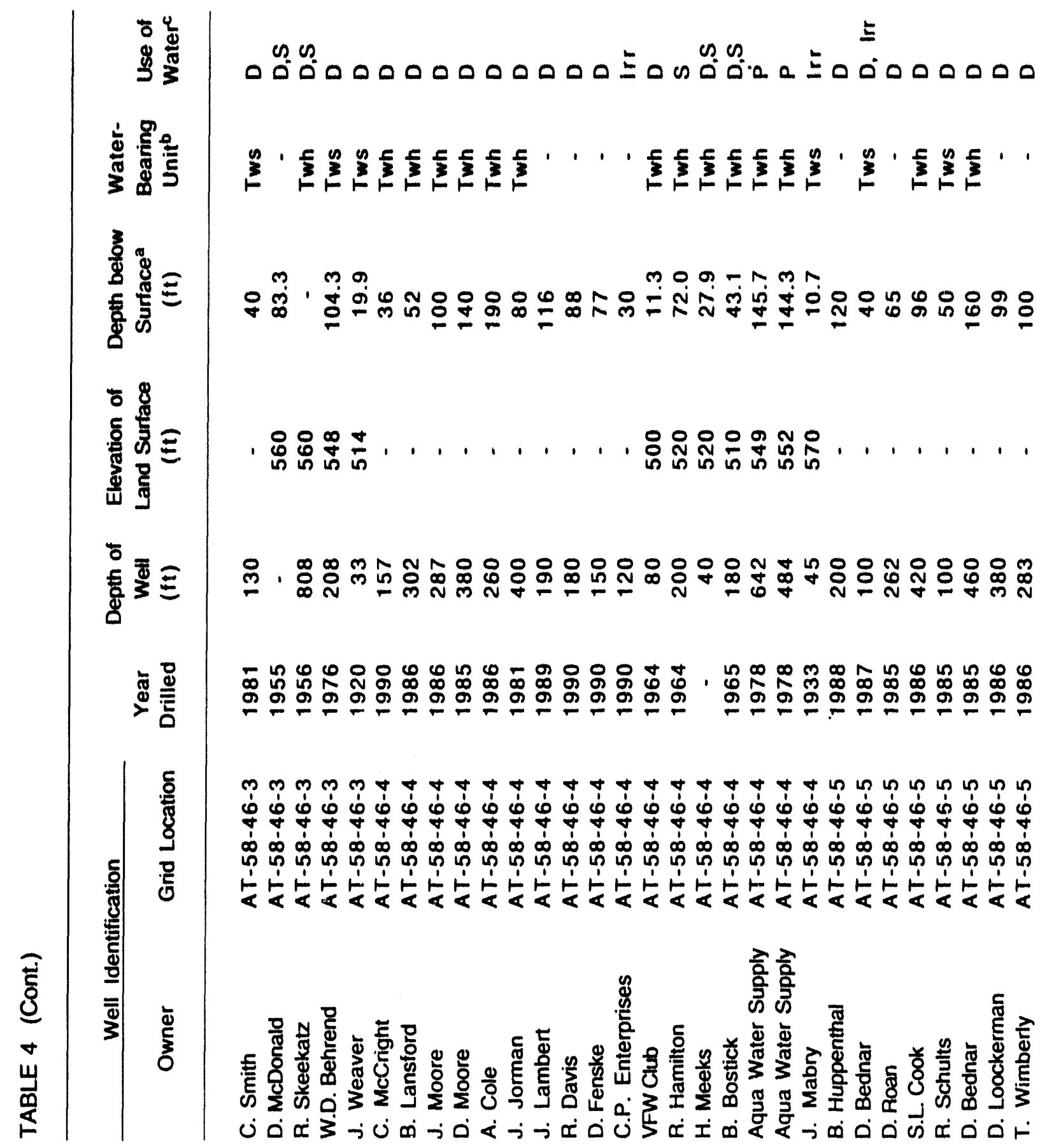




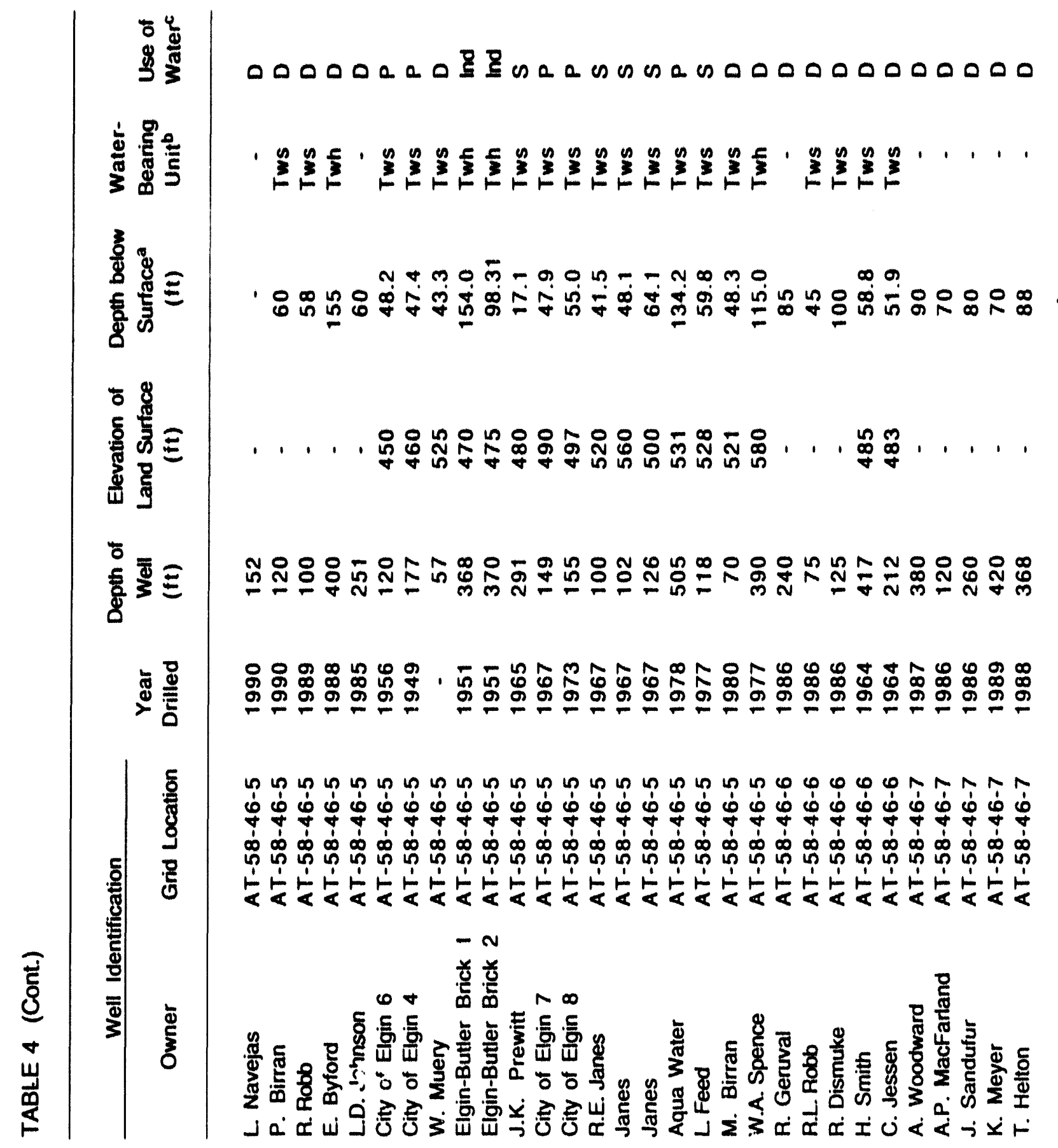




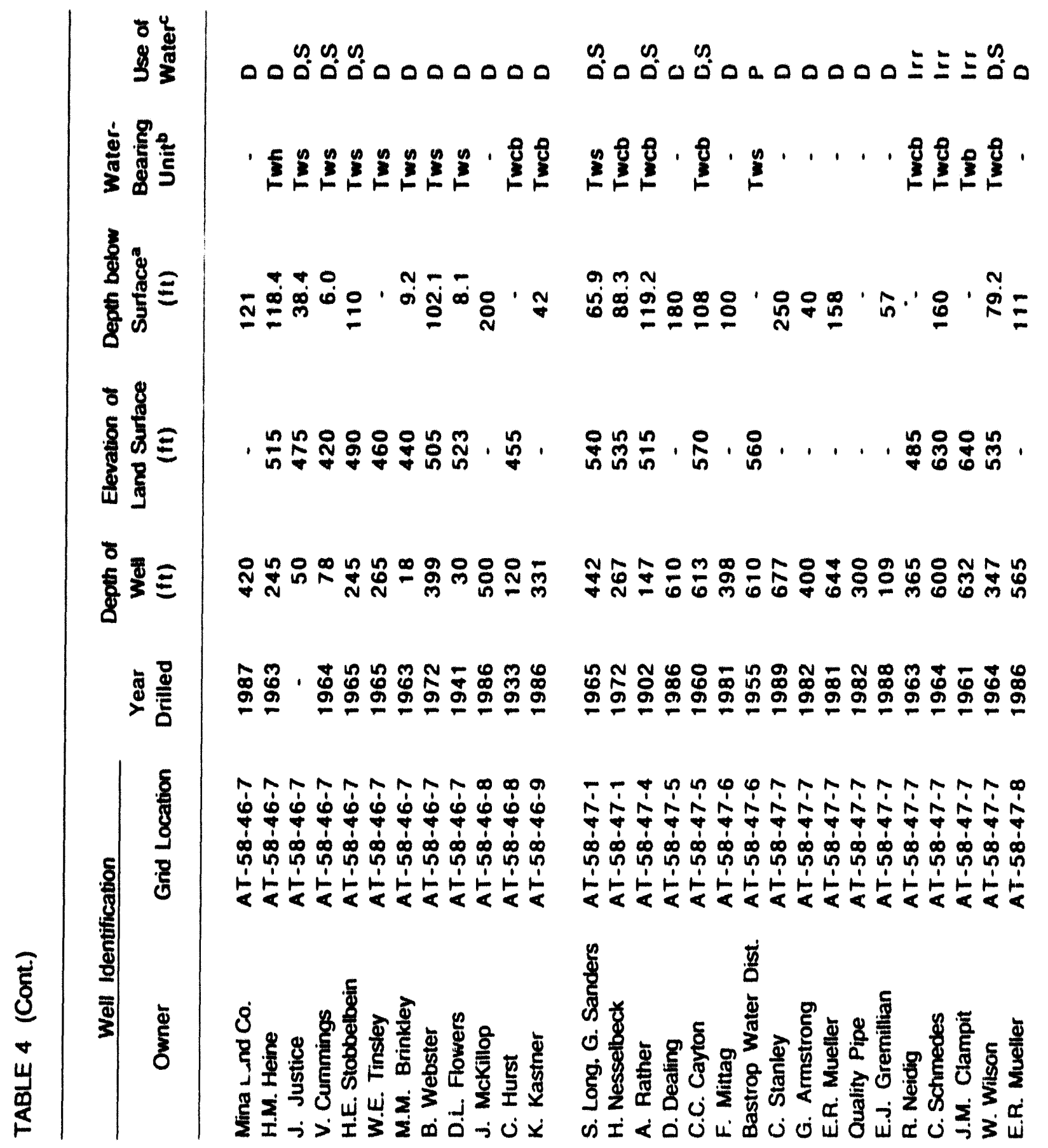




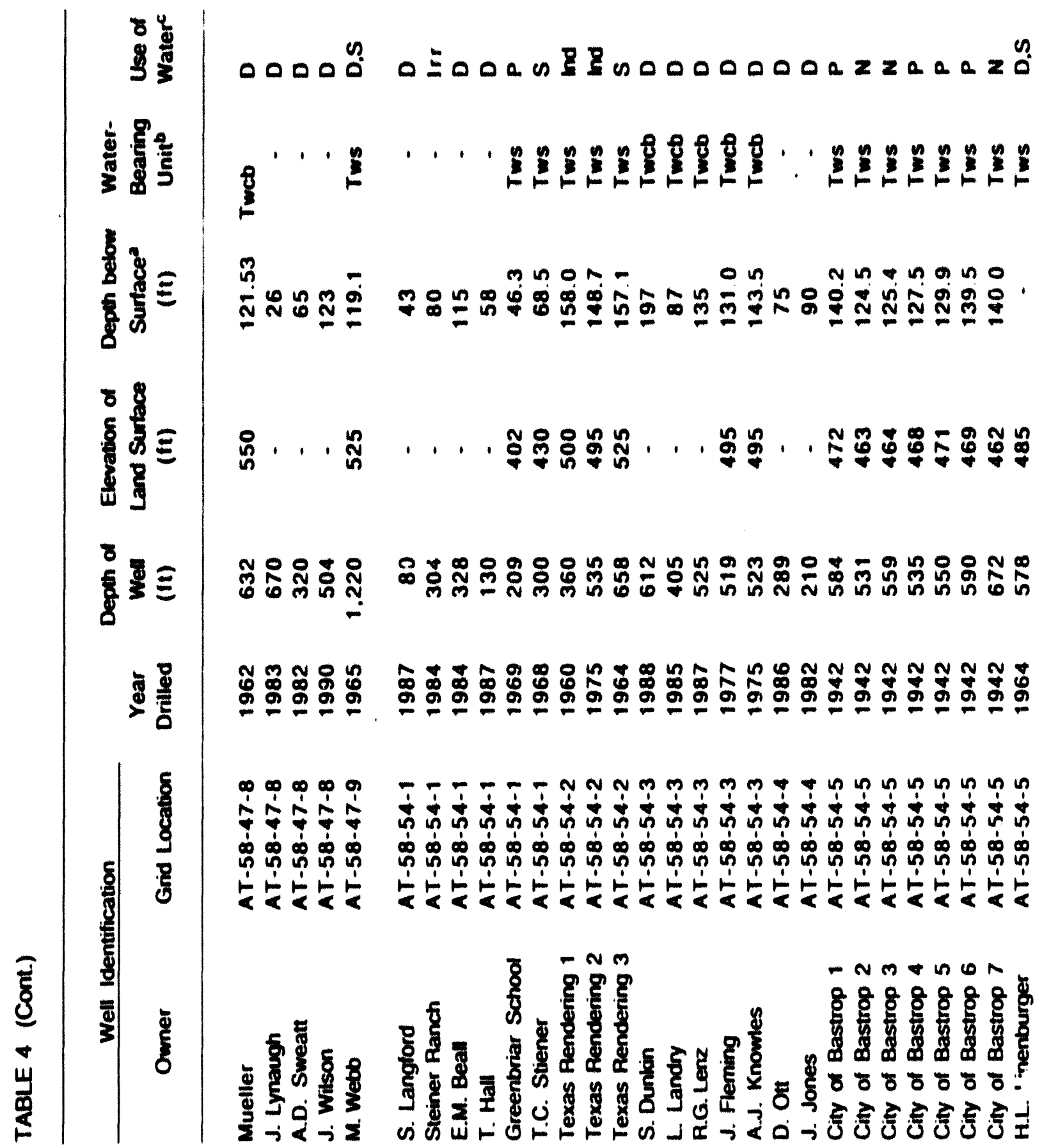




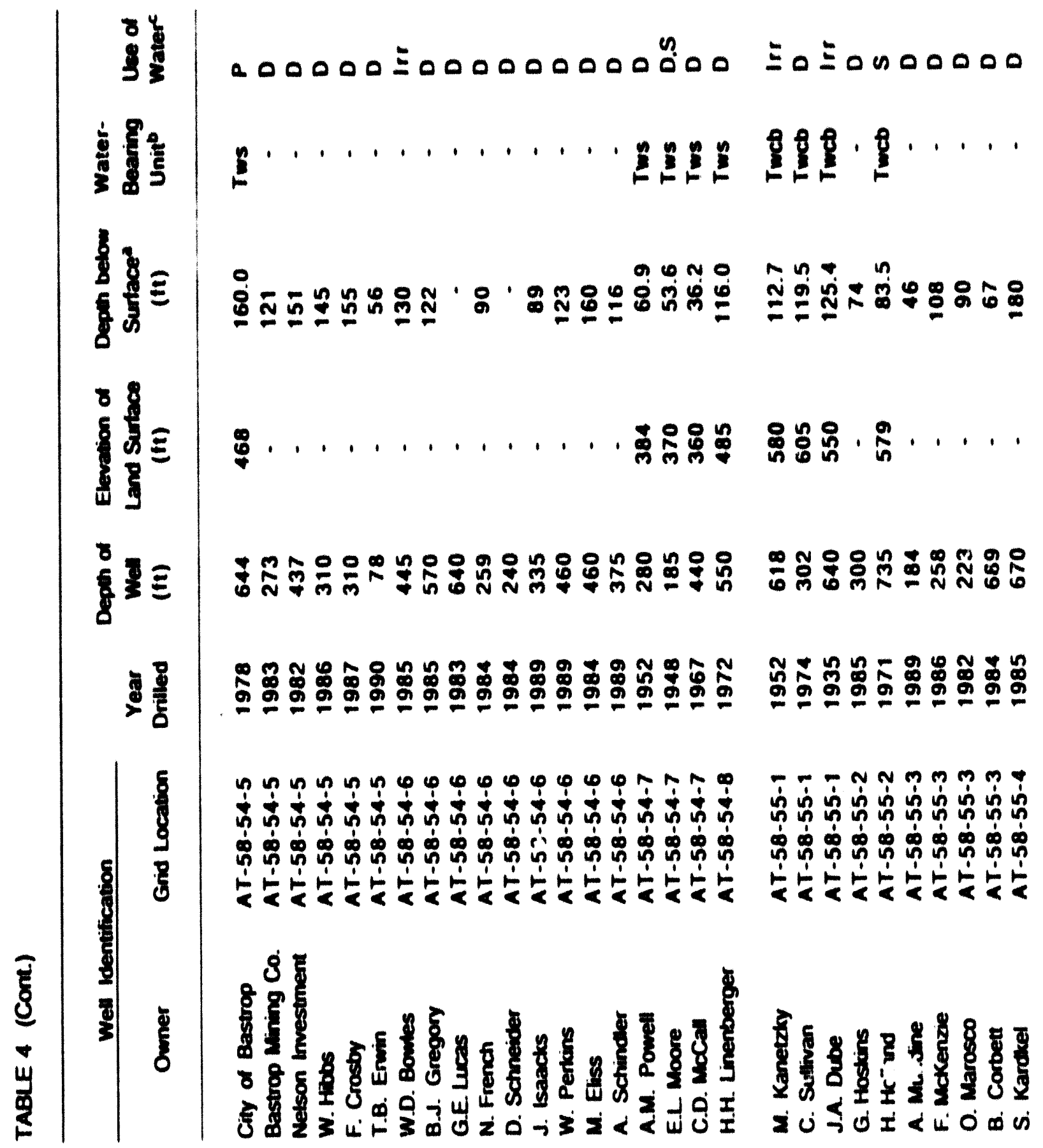




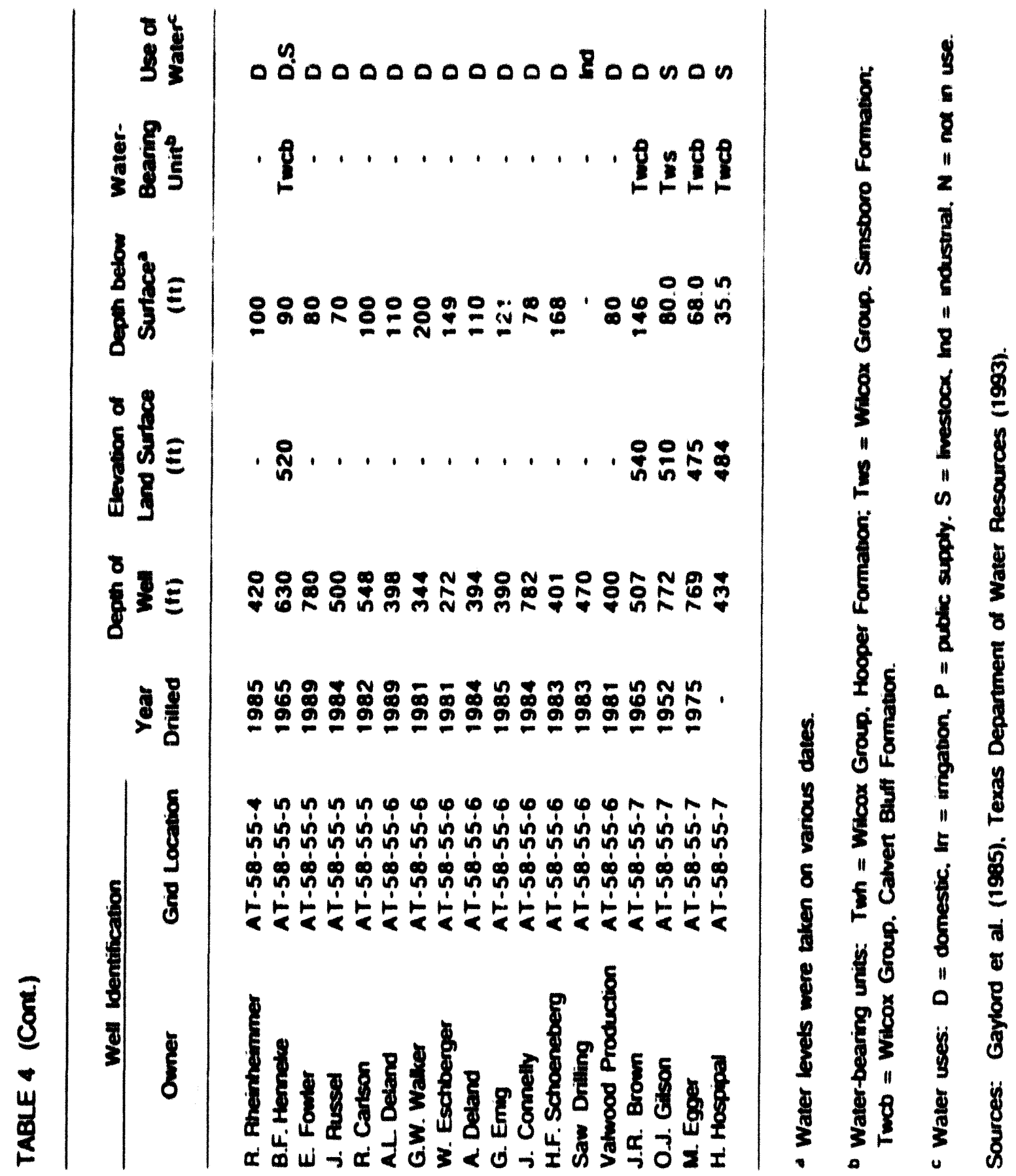


mulberry, red cedar, and box elder. Shrubs are dense in some stream side areas and include yaupon holly, poison ivy, and opossum-haw. The grassland area is covered with little bluestem, switch. Virginia bluestem, varieties of croton, ragweed, prickly pear, mesquite, scattered juniper, and loblolly pine (TXARNG 1988a).

Wildlife habitats on the property are closely associated with the various vegetation types, and the blending of these vegetation communities caused by the numerous openings throughout the area has resulted in high diversity and interspersion of animal species. A 1978 survey revealed the potential occurrence of 42 mummal, 119 bird. 80 herpetile, and 26 lish species. This diversity and the fact that hunting is restricted give Camp Swift many of the characteristics of a wildlife reserve (TXARNG 1988a).

Mammals include white-tuiled deer, gray fox, coyote, bobcut, raccoon, mink, beaver, jackrabbit, cottontail, squirrel, nutria. and skunk. Many raptors ure among the bird species expected to use habitats on Camp Swift. although only the turkey vulture, red-tuiled hawk. sparrow hawk, and great horned owl have been observed. Game birds present are waterfowl. wild turkey, mourning dove, and bobwhite quail. Locul wildlife officials believe that the Camp Swift wild turkey populution is probubly the only significant one in Bustrop County. Only one large pond and Big Sandy Creek have sufficient water to support lish, and sampling of these waters has identified the presence of several game species. Big Sandy Creek contains largemouth and Guadalupe bass, white crappie, bluegill. warmouth. longear sunlish, redbreast suntish, and green sunfish. Only the green sunfish has been identified in the large pond present on the property. The diverse herpetile community includes salamanders, several frogs and toads. turtles, lizards, and snakes. The toads are of purticular interest because Camp Swift is ubout $1.5 \mathrm{mi}$ from a designated critical habitat for the endangered Houston toad (Bufo houstonesis).

Camp Swift is a potential habitat for three federally listed endangered species: the American alligator, the bald eagle, and the Houston toud. Surveys for alligators in the area have not documented their presence on Camp Swift, and little suitable habitut for them is found on the property. Local wildlife officials consider the possibility of finding alligators at Camp Swift to be remote. Similarly, the possibility of seeing bald eagles on the property is negligible. Any presence would be transient because of the lack of a suitable nesting habitat. Camp Swift does contain potential habitut for the Houston toad. This habitat, lowse sands near ephemeral and permanent waters, was surveyed in 1979, but the presence of the species was not documented. When Camp Swift and adjacent areas were resuiveyed in 1982, Houston toads were observed within $0.5 \mathrm{mi}$ of the Camp Swift boundary, although none was observed on Camp Swift. 


\section{Environmentally Signiflcant Operations}

The PA team from Argonne identified four ESOs at Camp Swift: (1) storage of hazardous materials and hazardous waste. (2) underground storage of fuel and waste oil, (3) runoff of potentially contaminated waste water, and (4) detonation of explosives. Each ESU is described below. The ESO locutions are identified in Figures 2 and 3.

\subsection{Storage of Hazardous Materials and Hazurdous Waste}

Maintenance activities at the UTES 3 require the use of hazardous materials and the subsequent generation of hazardous waste. The volume of hazardous materials used at Camp Switt is low, however, as indicated in Section 2.2.1 and Table 2. New or unused hazardous materials are segreguted in enclosed storage locations with concrete lloors and sidewalls. These storage locations include the POL storage room and the battery storage room attached to Building 57 and the flammable muterials storage building next to Building 25. U:ed oils and solvents are collected in 55-gal drums and stored in the secured, covered, and fenced hazardous waste storage area. Each of these locked storage areas is inspected daily by TXARNC personncl during normal muintenunce activitics.

\subsection{Underground Storage of Fuel and Waste Oll}

Two USTs at the UTES are used for refueling of vehicles. Each tank has an 8.(0)()-gal capacity and is of double-walled fiberglass construction. The tanks were installed in 1987 by a certified contractor and were pressure tested to verify integrity. One tank is used for storage of MOGAS and one for storage of diesel fuel. The fuel-dispensing area is asphalt covered. $A$ 5,000-gal diesel fuel UST constructed of steel, which was installed in 1977, was removed on August 20, 1990 (TWC 1990).

A 500-gal steel UST near the tank lubricating rack of the UTES holds fluids drained during vehicle maintenance activities. The tank was installed with cathodic protection in 1987 by certified contractor and was pressure tested to verify its integrity. Waste vil removed during maintenance activities in the UTES is poured into this UST. In addition, floor drains within the UTES. including an urea for washing vehicles and equipment, direct waste lluids to an oil-water separator. Waste oil from the separator is then directed to the 500-gal waste oil UST. When the UST is full. 
the waste oil is pumped out and transferred to 55-gal drums for transport to the DRMO for disposal.

\subsection{Runoff of Potentially Contaminated Waste Water}

Potentially contaminated waste water includes vehicle/equipment washwater and surface drainage from the asphalt-covered fuel-dispensing area or the hazardous materials/hazardous waste storage areas. Use of the vehicle and tank wash areas at the Camp Swift UTES facility is currently on hold pending interconnection with the regional waste water treatment facility located approximately $3 \mathrm{mi}$ south of Camp Switt and issuance of an NPDES permit. In past years, washwater from the UTES 3 area was discharged to a ditch adjacent to the UTES 3, leading to the Big Sandy Creek. Runoff from the asphalt-covered fuel-dispensing area goes to the surrounding surface soils.

\subsection{Detonation of Explosives}

Training exercises at Camp Swift include the firing of weapons and detonation of explosives, as described in Section 2.2.3. Units using the range facilities are subject to the safety procedures and firing restrictions outlined in the standard operating procedures for units conducting training at Camp Swift (TXARNG 1989). Unexploded ordnance dating from World War II has been found in widely scattered areas throughout Camp Swift. 


\section{Known and Suspected Releases}

\subsection{Releases to Groundwater}

Underground storage of fuel or oil is a potential source of groundwater contamination if the UST should leak or rupture. Currently, three USTs at the UTES contain gasoline, diesel fuel, and waste oil. A fourth UST installed in 1977 for storage of diesel fuel was excavated in 1990. Current USTs were pressure tested when they were installed in 1987 to verify their integrity. Tank contents are checked daily by inventory, and pressure testing is performed annually. Fuel USTs are constructed of fiberglass and are double walled to minimize the potential for leakage. Frequent monitoring of the waste oil inventory ensures early detection of any leakage from the waste oil UST that might occur.

\subsection{Releases to Surface Water}

No documentation of on-site releases to surface water was found during the site visit, nor was any evidence of adverse impact observed.

\subsection{Releases to Soil}

Current and former maintenance activities performed at the UTES 3 facility could release minor quantities of hazardous chemicals to the surface and subsurface soils. Minor amounts of fuel may be released to surface soils during vehicle fueling and fuel UST refilling operations as a result of runoff from the asphalt-covered surface surrounding the fuel-dispensing island. Inadvertent spills of oil or solvent in the bermed storage area for waste fluid drums would result in minor contamination of surface soils within the bermed area. Past use of the Building 57 wash area resulted in the discharge of filtered waste washwater from the oil-water separator to the ditch south of Building 57. Given the distance to the nearest surface water, this waste water was most likely absorbed by the soil. 


\subsection{Releases to Air}

Routine operations performed as part of current TXARNG operations do not result in the release of significant quantities of hazardous materials to the air. Fugitive dust and emissions that result from the use of vehicles during training exercises and particles released during minor welding, sanding, and painting operations are discounted as an ESO.

A survey performed in early 1993 for the U.S. Army Corps of Engineers confirmed the presence of asbestos in some construction materials used in certain Camp Swift buildings. These materials include floor tiles and mastic, vent caulking, and interior Transite siding (USACE 1993). A total of 29 bulk samples of building materials were collected from 7 of the 50 buildings inspected at Camp Swift. Five samples from three of the buildings inspected were found to contain $1 \%$ or more of asbestos. Asbestos-containing materials (ACMs) included floor tiles and mastic in Building 25, vent caulking in Building 57, and interior Transite siding in Building 5 and Building 7. Table 5 summarizes the samples of building construction materials containing asbestos. No ACM identified at Camp Swift is friable, and none is considered to constitute a health hazard to building occupants in its present condition. Recommendations for monitoring and abatement of the nonfriable ACMs were made in the survey report.

\subsection{Other Releases}

Numerous acid spiils, the result of acid leaking from cracked batteries, are evident in the UTES battery storage room in Building 57. The pitch of the storage room floor allows the acid to seep into the adjacent POL storage room. This flow would constitute a hazard if incompatible materials came into contact within the POL storage room.

The operation of vehicles and aircraft assigned to the unit results in increased noise levels, as does the firing of weapons during training exercises. Infrequent complaints of noise resulting from weapons fire have been received. Restrictions on trainin's activities involving the use of explosive munitions were instituted to minimize annoyanre to nearby residents (Hill 1980).

Fire and explosion could result from an accident involving a vehicle or aircraft assigned to the unit or from weapons fire. Unexploded World War II ordnance, primarily 75-mm antitank rounds and bazooka rounds, have been found in widely scattered areas throughout Camp Swift. 
TABLE 5 Samples of Bullding Construction Materials Containing Asbestos

\begin{tabular}{lllcl}
\hline Sample & $\begin{array}{c}\text { Asbestos-Containing } \\
\text { Material }\end{array}$ & Condition of Material & $\begin{array}{c}\text { Amount of } \\
\text { Material } \\
\left(\mathrm{ft}^{2}\right)\end{array}$ & $\begin{array}{c}\text { Asbestos Type, } \\
\text { Amounta }\end{array}$ \\
\hline CS8-10 & Vent caulking & Undamaged, nonfriable & 50 & Chrysotile, 10\% \\
CS46-02 & White floor tile & Damaged, nonfriable & 40 & Chrysotile, 5\% \\
& Tile mastic & Damaged, nonfriable & 40 & Chrysotile, $0 \%$ \\
CS46-03 & Brown floor tile & Damaged, nonfriable & 222 & Chrysotile, 3\% \\
& Tile mastic & Damaged, nonfriable & 222 & Chrysotile, 0\% \\
CS44-07 & White floor tile & Undamaged, nonfriable & 580 & Chrysotile, 5\% \\
& Tile mastic & Undamaged, nonfriable & 580 & Chrysotile, 0\% \\
\hline
\end{tabular}

When more than one analytical result is available, the highest value is reported.

Source: USACE (1993).

When it is discovered, ordnance is usually on top of the ground or very near the surface, still explosive in spite of its age and weathered condition. No concentration of ordnance is known (DOI 1980). 


\section{Human and Environmental Receptors}

\subsection{Groundwater}

Groundwater is a source of potable water in the vicinity of Camp Swift. Registered wells within a 4-mi radius of the facility are described in Section 2.5.4.4. Most wells withdraw from the Simsboro Formation, which is beneath the Calvert Bluff Formation. Some wells are located in the lower Hooper Formation. Given the depth to groundwater and the presence of relatively impermeable geologic units (lignite and clay) within the Calvert Bluff Formation above the Simsboro aquifer, minor surface and subsurface soil contamination within the Calvert Bluff Formation that could result from activities at Camp Swift would be very unlikely to affect the deeper groundwater supplies.

\subsection{Surface Water}

Drainage or any surface spills from the UTES would have to travel approximately 0.25-0.33 mi over a relatively gentle slope to reach Dogwood Creek, one of the two named intermittent streams on the property, or over $1 \mathrm{mi}$ to reach Big Sandy Creek. Big Sandy Creek joins the Colorado River approximately $6 \mathrm{mi}$ downstream. In spite of the low infiltration rate of the surface soils, surface runoff from Camp Swift is unlikely to result in any major environmental impact to the surface water in the area.

\subsection{Soll}

Access to the Camp Swift UTES facility is restricted to National Guard personnel and escorted visitors. Workers in areas where surface soil contamination is most likely to be present, such as at the hazardous waste storage area, are appropriately trained about potential hazards. The distance from areas of potential surface soil contamination to perennial surface water flows would preclude transport of surface contaminants to areas outside the TXARNG property. 


\subsection{Air}

Site personnel are exposed to minor releases of contamination to the air during regular vehicle operation and maintenance activities. Dust masks or filters are used when appropriate (during welding, sanding, pairting, etc.) to reduce the level of exposure. Exposure by air of the off-site population to contamination generated by activities at Camp Swift is unlikely. A survey of site facilities in 1993 determined that asbestos present on the site in the form of construction materials is nonfriable.

\subsection{Other Receptors}

Access to the property by civilians is controlled by fencing. Therefore, the threat of injury as a result of weapons fire or explosion is limited to on-site personnel, other TXARNG officials, and authorized visitors to the property. Most flammable materials are stored in USTs or fully approved butane and propane tanks. Strict safety precautions govern the use of and entry to site firing ranges (TXARNG 1989). 


\section{Preliminary Assessment Findings and Conclusions}

\subsection{Summary of Preliminary Assessment Findings}

The Camp Swift Military Reservation is a 11,740-acre training facility located in northern Bastrop County, Texas, approximately $8 \mathrm{mi}$ north of the city of Bastrop. Camp Swift is $30 \mathrm{mi}$ east of the city of Austin, which is located in Travis County. Military training activities include tank maneuvers, airfield training, parachute drops, and firearms practice and qualification. Specialized courses include three compass courses, a helicopter slalom course, and a squad-sized chemical warfare training chamber. Organizational maintenance support is provided through the UTES 3. Housing is currently available for approximately 400 persons. The primary ESOs associated with the property are (1) storage of hazardous materials and hazardous waste, (2) underground storage of fuel and waste oil, (3) drainage from operations at UTES 3, and (4) weapons firing, including the presence of unexploded ordnance.

This PA of Camp Swift was performed to determine the potential for hazardous constituents that may be present on site as a result of current or past operations to migrate beyond the property boundary to areas of human or environmental concern. The volumes of hazardous materials used at the facility (e.g., fuel, oil, solvents) and hazardous wastes generated are low. Fuel oil (two 8,000-gal USTs) and waste oil (one 500-gal UST) stored underground constitute the greatest volume of hazardous materials present. Although groundwater is used as a source of drinking water in the vicinity, the intervening layers of lignite and clay in the subsurface and the depths of the wells reduce the risk of impact to groundwater from TXARNG activities. The property is within the Colorado River drainage basin, and intermittent and perennial streams within the property flow toward the river, which is located approximately 6 mi downstream. Runoff of hazardous materials at the property, including inadvertent spills of fuel during refueling operations, is minimal and is not considered to significantly affect nearby surface waters. Live weapons fire does occur at the facility as part of training activities, and unexploded ordnance has been found on the site. The reservation is secured by a fence, and precautions are taken to prevent unauthorized entry to the demolition area.

\subsection{Recommendations for Further Action}

The primary objective of the PA is to identify and evaluate ESOs that would result in either (1) immediate action, (2) site investigation, or (3) no further PA/IRP action. Generally, the 
available information indicates that the Camp Swift Military Reservation is well maintained and poses minimal potential threat to human health and the environment. No further PA/IRP action is warranted. However, the following two situations at the UTES should be addressed to avoid any future environmental or health risk:

- The wall adjoining the battery storage room and the POL storage room in the UTES should be curbed to prevent leakage of materials into either room. Leakage from the present battery acid room into the POL storage room could result in the generation of incompatible and potentially flammable materials.

- At the time of the site visit, interconnection of the UTES facility to a regional waste water treatment facility was planned. Drainage of waste water from the oil-water separator at the UTES may require permitting under the NPDES program or under local industrial waste discharge regulations. Contact with local authorities is recommended. Periodic sampling of the effluent may satisfy the regulations pertinent to the discharge. 


\section{References}

Baker, F.E., 1979, Soil Survey of Bastrop County, Texas, U.S. Department of Agriculture, Soil Conservation Service, March.

Bennett, J.W., 1985, Correspondence between Bennett, Supply Management Officer, Texas Army National Guard, and J. Martin, Texas Department of Health, Bureau of Solid Waste Management, regarding a request for a Texas Department of Health identification number for activities related to solid waste management, February 14.

Brune, G., 1983, Occurrence, Availability, and Quality of Groundwater Resources in Travis County, Texas, Texas Department of Water Resources, Report No. 276, June.

Dennis, C.B., 1993, Unpublished site reconnaissance and interview notes for preliminary assessment of Camp Swift, Bastrop County, Texas, May.

DOI, 1980, Draft Environmental Impact Statement for the Proposed Competitive Leasing of Lignite Reserves at Camp Swift Military Reservation, Bastrop County, Texas, U.S. Department of the Interior, Bureau of Land Management, New Mexico State Office, September.

DOI, 1982, Final Camp Swift. Texas, Petition Evaluation Document, Report No. 522 SMCRA. Evaluation OSM-PE-4, U.S. Department of the Interior, Office of Surface Mining Reclamation and Enforcement, August.

DOD, 1982, Unpublished memorandum from J.D. Moore, Department of the Army, Southwestern District, San Antonio, Texas, to The Adjutant Generul, Texas Army National Guard, Elgin, Texas, regarding a survey of the Army's real property holdings at Camp Swift, Texas, Letter Report 82-504, February 26.

EPA, 1989, Sewage Treatment Facility Design and Construction, Federal Agency Pollution Abatement Plan Project Report filed by C.J. Hall, Texas nimy National Guard, with the U.S. Environmental Protection Agency, February 16.

Follett, C.R., 1970, Groundwater Resources of Bastrop County, Texas, U.S. Geological Survey, Texas Water Development Board Report 109, March. 
Gaylord, J.L., R.M. Slade, Jr., L.M. Ruiz, C.T. Welborn, and E.T. Baker, Jr., Water Resources Appraisal of the Camp Swift Lignite Area. Central Texas, U.S. Geological Survey, WaterResources Investigations Report 84-4333.

Hamilton, W.S., 1990, Camp Swift UTES Site Plan, Fisher, Hagood, Hamilton, and Heil, Texas Registered Professional Land Surveyor No. 4072, Round Rock, Texas, September 7.

HDR, 1991, Contract Drawings for the Construction of Camip Swift Regional Wastewater Treatment Facility, Project Number 00057-002-036, HDR Engineering, Inc., Austin, Texus, July.

Hill, W.D., 1980, Unpublished memorandum from Hill, Brigadier General, Texas Army National Guard, regarding use of explosive munitions and demolitions at Camp Swift, May 8.

Larkin. T.J., and G.W. Bomar, 1983, Climatic Allas of Texas. Texas Department of Water Resources Report LP-192, p. 151.

NGB, 1986, Unpublished memorandum from Colonel J.R. D'Araujo, Jr., National Guard Bureau. Army Organization and Training Division. Fulls Church. Virginia, to The Adjutant General of Texas, about the sizing of the training site at Camp Swift. Texas, July 21.

NGB, 1988, Army National Guard Facilities Inventory and Stationing Plan (F/SP), U.S. Army National Guard Bureau, Aberdeen, Maryland, January.

Patterson, J.L., 1963, Floods in Texas - Magnitude and Frequency of Peak Flows, U.S. Geological Survey, Texas Water Commission Bulletin 6311. December.

Rand McNally, 1992. Rand McNally 1992 Atlas, Rand McNally and Company, Chicago, Illinois.

Senger, R.K., C.W. Kreitler, and W.L. Fisher, 1984, Hydrogeology of the Edwards Aquifer, Austin Area, Central Texas, Report No. 141. University of Texus at Austin. Bureau of Esonomic Geology.

TDWR, 1993, Texas Department of Water Resources, records of wells filed with the stute of Texas through the Texas Water Well Drillers Board. 
Thorkildsen, D., and R.D. Price, 1991, Groundwater Resources of the Carrizo-Wilcox Aquifer in the Central Texas Region. Texas Water Development Board Report 332. September.

TXARNG, 1988a, Master Plan - Camp Swift, Texas Army Nutional Guard, Austin. Texas, March 11.

TXARNG, 1988b, Spill Prevention Control and Countermeasure Plan (SPCCP) and Installation Spill Contingency Plan (ISCP) for Camp Swift. Bastrop County, Texas, prepared by Clifford J. Hall, P.E. Water Quality Engineering Consultation No. 32-62-0177.88, for Texas Army National Guard, Austin, Texas, February.

TXARNG, 1989, Unpublished memorandum from ILT J.A. Junot, Texas Army National Guard, Bastrop. Texas, to The Adjutant General of Texas, Austin, Texas, regarding standard operating procedures at Camp Swift, July 14.

TWC, 1990, Unpublished letter from W.J. Young, Texas Water Commission, to C.J. Hall, Texas Army National Guard, requesting additional information regarding removal of underground storage tanks at the UTES 3, August 20.

USACE, 1993, Ashesios Survey - Camp Swift. Highway 95 North. Bastrop Countr. Te.xas. report prepared for the U.S. Army Corps of Engineers, Fort Worth District, by Geo-Murine, Inc., Plano, Texas, Contract No. DACA63-90-D-0061, Delivery Order No. 0044, February.

USGS, 1982a, U.S. Geological Survey, Topographic Map - Elgin East, Texas, Quadrangle, No. 3015.W9715/7.5.

USGS, 1982b, U.S. Geological Survey, Topographic Map - Lake Bastrop, Texas, Quadrangle, No. N3007.5-W9715/7.5.

USGS, 1982c, U.S. Geological Survey, Topographic Map - McDade, Texas, Quadrangle, No. 3015-W9707.5/7.5.

USGS, 1982d, U.S. Geological Survey, Topographic Map - Smithville NW, Texas, Quadrangle, No. N3007.5-W9707.5/7.5. 


\section{Appondix:}

Intorviow Information 


\section{Appendix:}

Intervlew Information

\section{Indlviduals and Agencies Interviewed}

\section{Environmental Officer}

Texas Army National Guard

Camp Mabry

Austin, Texas

Construction In'spector (retired)

Texas Army National Guard

Camp Mabry

Austin, Texas

Texas Water Commission

Well Drillers Board

Austin, Texas

U.S. Department of Agriculture

Soil Conservation Service

Austin, Texas

\section{U.S. Geological Survey}

Texas Water Development Bourd

Austin, Texas

\section{Argonne Investigators}

\section{Clyde Dennis}

(708) 252.5999

George Hildebrandt

(708) 252-4991

Canduce Rose

(708) 252-3499 

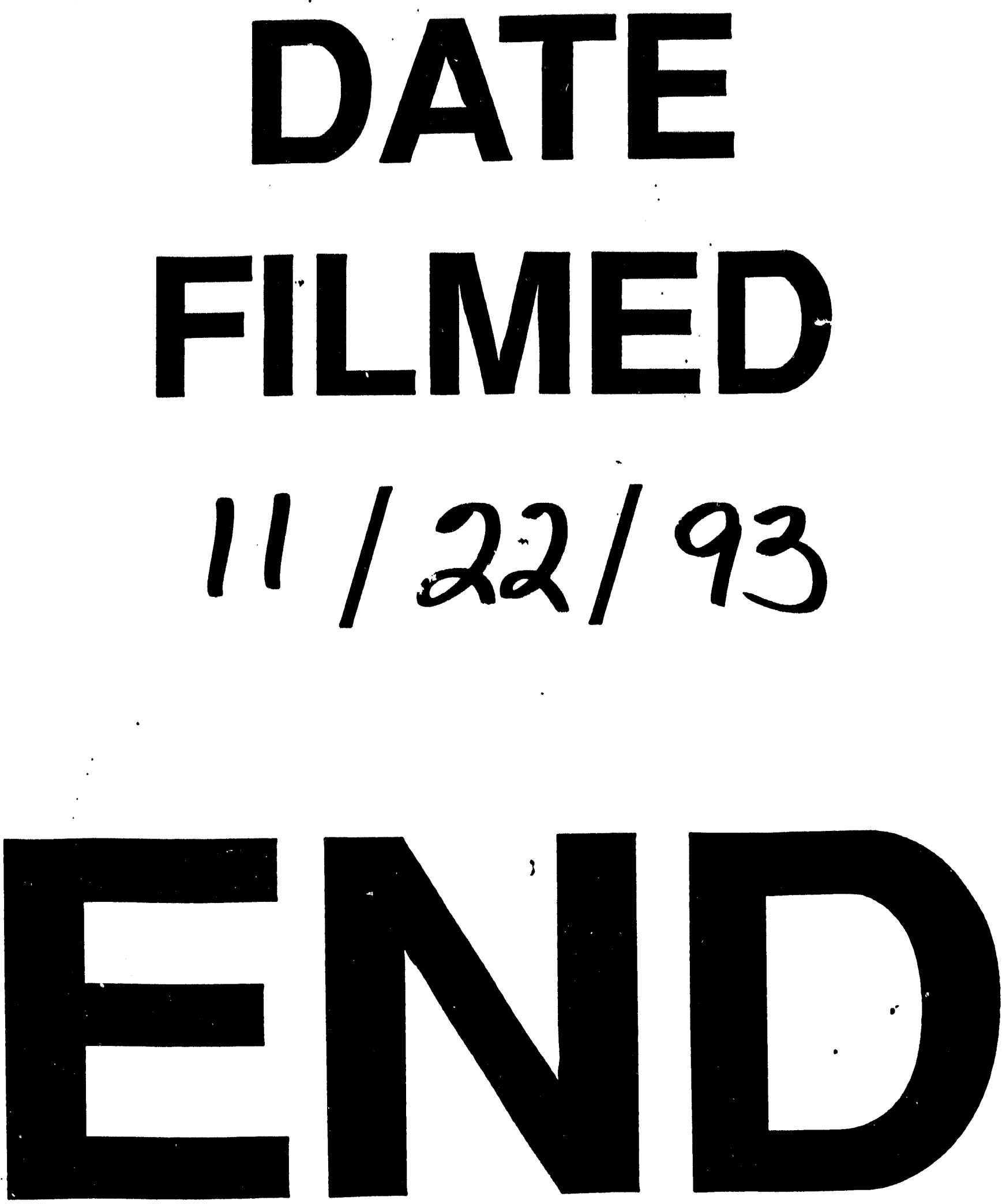


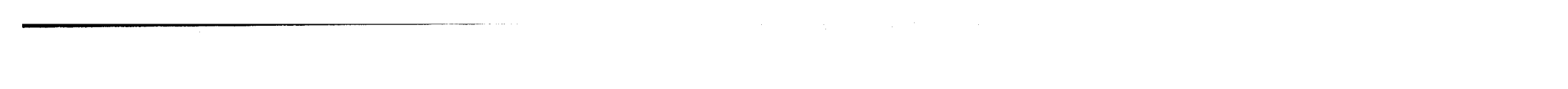

